\title{
Versatile Phosphite Ligands Based on Silsesquioxane Backbones
}

\author{
Jarl Ivar van der Vlugt, ${ }^{a}$ Jens Ackerstaff, ${ }^{a}$ Tessa W. Dijkstra, ${ }^{a}$ Allison M. Mills, ${ }^{b}$
} Huub Kooijman, ${ }^{\mathrm{b}}$ Anthony L. Spek, ${ }^{\mathrm{b}}$ Auke Meetsma, ${ }^{\mathrm{c}}$ Hendrikus C. L. Abbenhuis, ${ }^{a}$ Dieter $\operatorname{Vog}^{\mathrm{a}, *}$

a Schuit Institute of Catalysis, Laboratory of Homogeneous Catalysis, Eindhoven University of Technology, P. O. Box 513, $5600 \mathrm{MB}$ Eindhoven, The Netherlands

Phone: (+ 31)-40-247-2483. fax: (+31)-40-245-5054, e-mail: d.vogt@tue.nl

b Bijvoet Research Institute, Laboratory for Crystal and Structural Chemistry, Department of Chemistry, Utrecht University, Padualaan 8, $3584 \mathrm{CH}$ Utrecht, The Netherlands

Crystal Structure Center, Chemical Physics, Materials Science Center, University of Groningen, Nijenborgh 4, 9747 AG Groningen, The Netherlands

Received: October 21, 2003; Accepted: February 26, 2004

Abstract: Silsesquioxanes are employed as ligand backbones for the synthesis of novel phosphite compounds with 3,3'-5,5'-tetrakis(tert-butyl)-2,2'-dioxa-1,1'-biphenyl substituents. Both mono- and bidentate phosphites are prepared in good yields. Two types of silsesquioxanes are employed as starting materials. The monophosphinite $\mathbf{1}$ and the monophosphite $\mathbf{2}$ are prepared from the thallium silsesquioxide derived from a completely condensed silsesquioxane framework $\left(c-\mathrm{C}_{5} \mathrm{H}_{9}\right)_{7} \mathrm{Si}_{7} \mathrm{O}_{12} \mathrm{SiOTl}$. The diphosphite $\mathbf{3}$ is synthesized starting with the incompletely condensed monosilylated disilanol (c$\left.\mathrm{C}_{5} \mathrm{H}_{9}\right)_{7} \mathrm{Si}_{7} \mathrm{O}_{9}\left(\mathrm{OSiMePh}_{2}\right)(\mathrm{OH})_{2}$. For monophosphite 2 , the corresponding trans- $\left[\mathrm{PtCl}_{2}(2)\right]$ complex 4 is characterized by NMR spectroscopy as well as by Xray crystallography, as the first example of a com- pletely condensed oxo-functionalized silsesquioxane framework. The coordination of the bidentate ligand 3 towards Pd, Mo and Rh is studied, both by NMR spectroscopy as well as by X-ray crystallography. Various modes of coordination are shown to be possible. The molecular structures for the complexes trans- $\left[\mathrm{PdCl}_{2}(\mathbf{3})\right](\mathbf{5})$, cis- $\left[\mathrm{Mo}(\mathrm{CO})_{4}(\mathbf{3})\right](\mathbf{6})$ and the dinuclear complex $\left[\{\mathrm{Rh}(\mu-\mathrm{Cl})(\mathrm{CO})\}_{2}\left(\kappa^{2}-3\right)\right](7)$ have been determined. In the rhodium-catalyzed hydroformylation of 1-octene high activities, with turnover frequencies of up to $6800 \mathrm{~h}^{-1}$, are obtained with these new nanosized phosphorus ligands.

Keywords: coordination chemistry; homogeneous catalysis; ligand design; phosphorus; silsesquioxanes

\section{Introduction}

Polyhedral oligomeric silsesquioxanes (or POSS for short $)^{[1,2]}$ have now been well established as versatile, nanostructured and oxidatively inert materials that can be readily synthesized on a large scale. ${ }^{[3]}$ These molecular spherosilicates with the general formula $\left[\mathrm{RSiO}_{3 / 2}\right]_{\mathrm{n}}$, in which $\mathrm{R}$ stands for an (in)organic group and with typical values for $n$ of $6,8,10$ or 12 , can be obtained with a closed or completely condensed framework or with an incompletely condensed silsesquioxane structure (Figure 1). Usually, with R being a (cyclo)alkyl unit, these compounds are well soluble in a range of organic solvents (e.g., THF, toluene, $\mathrm{CH}_{2} \mathrm{Cl}_{2}$, hexane, $\mathrm{Et}_{2} \mathrm{O}$ ), and they show good stability in acidic and moderate stability in basic reaction media. Together with their thermal stability up to temperatures above $200^{\circ} \mathrm{C}$, these characteristics provide a good basis for further investigation of the applicability of these well-defined structures.
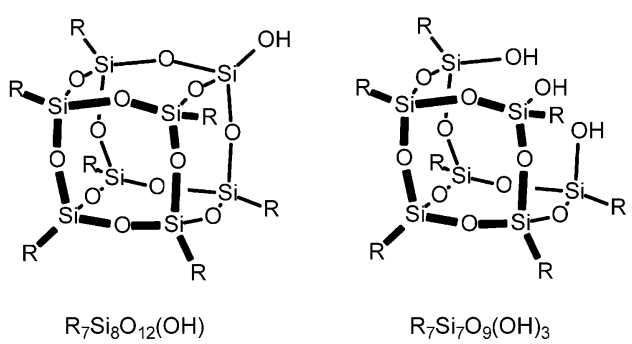

Figure 1. Representations of a completely condensed silsesquioxane with a monosilanol functionality (left) and an incompletely condensed trisilanol silsesquioxane (right).

They have been extensively studied for several years as homogeneous models for silica supports ${ }^{[4]}$ and as building blocks for inorganic or hybrid materials. ${ }^{[5]}$ The rich silanolate coordination chemistry, ${ }^{[6]}$ involving main group but also early and late transition metals, as well as the applications of silsesquioxanes in both homogeneous and heterogeneous catalysis have been reviewed. ${ }^{[7]}$ 
Particularly the area of catalytic epoxidation is subject of ongoing investigation by several groups, ${ }^{[8]}$ with silsesquioxane metal complexes reported to be stable in $1 \mathrm{M}$ hydrochloric acid. ${ }^{\left[{ }^{a}\right]}$ However, the synthesis and application of phosphorus ligands based on silsesquioxane frameworks has hardly received any attention to date. ${ }^{[9]}$ In addition, most of the systems reported to date are peripherally functionalized (dendritic) silsesquioxanes containing phosphine moieties, tethered by various (mainly alkyl) spacers. ${ }^{[10,11]}$

Silsesquioxanes are reported to have electron-withdrawing character similar to conventional silica. ${ }^{[2]}$ Previous studies with simple electron-withdrawing phosphites already showed interesting effects on the regioselectivity and reaction rates in hydroformylation. ${ }^{[13]}$ Our research goal was therefore the development of new P-containing ligands, based on these stable silsesquioxane backbones with their unique properties, by functionalization of silanol groups with suitable phosphorus moieties. This would open up a rather unexplored field of ligand design, leading to new possibilities for coordination chemistry and homogeneous catalysis. Due to their nanoscopic dimensions, these molecules might lead to new, stable catalyst supports for continuous homogeneous catalysis with integrated membrane separation. ${ }^{[14]}$ Since these silsesquioxanes are also good models for silica surfaces, even a link towards heterogeneous phase catalysis can be foreseen.

We have previously reported on the synthesis and application of incompletely condensed silsesquioxanebased monophosphites ${ }^{[15]}$ as well as on the synthesis, electronic properties and coordination chemistry of a novel silsesquioxane-based diphosphinite ligand. ${ }^{[16]}$ In the present work we describe the design of two monodentate compounds $\mathbf{1}$ and $\mathbf{2}$ as well as a bidentate phosphite compound $\mathbf{3}$ (Figure 2). The synthesis of the three ligands is presented together with the coordination behaviour of diphosphite $\mathbf{3}$ towards palladium, molybdenum and rhodium. As a first and preliminary test reaction to show the applicability of both phosphite compounds we have chosen the rhodium-catalyzed hydroformylation of 1-octene, a well-known and widely studied model reaction with industrial relevance.

The first applications of phosphite ligands in the rhodium-catalyzed hydroformylation of 1-alkenes were reported by Pruett and Smith at Union Carbide. ${ }^{[17]}$ Phosphites are generally better $\pi$-acceptors than phosphines and therefore have great potential in hydroformylation. The metal-CO bond is weakened, leading to accelerated $\mathrm{CO}$ dissociation and hence higher reaction rates compared to phosphines. Other advantages include the generally straightforward synthesis of phosphites and their stability towards oxidation. Reports based on bulky monophosphites ${ }^{[18]}$ often showed high reaction rates, but most systems suffered from a low regioselectivity, which is still a common feature of monodentate ligands. Bidentate diphosphite ligands have been developed to circumvent this problem. ${ }^{[19]}$ Based on catalytic tests the bridge length between the two phosphorus atoms appeared to have a large influence on the selectivity of linear aldehyde.

\section{Results and Discussion}

\section{Synthesis of Ligands 1-3}

The incompletely condensed silsesquioxane trisilanol $\left(c-\mathrm{C}_{5} \mathrm{H}_{9}\right)_{7} \mathrm{Si}_{7} \mathrm{O}_{9}(\mathrm{OH})_{3}$ can be corner-capped with $\mathrm{SiCl}_{4}$, leaving a chloro-functionalized silsesquioxane. By hydrolysis the corresponding monosilanol can be obtained. ${ }^{[20]}$ To enhance the reactivity of the siloxy group the silanol is best converted into thallium silsesquioxide A. ${ }^{[21]}$ The reaction of this thallium silsesquioxide with $\mathrm{ClPPh}_{2}$ led to the sole formation of the corresponding monophosphinite $\mathbf{1}$. This compound was fully characterized using ${ }^{1} \mathrm{H},{ }^{13} \mathrm{C}$ and ${ }^{31} \mathrm{P}$ NMR spectroscopy as well as by elemental analysis. Encouraged by this proof of principle that a completely condensed silsesquioxane can be modified with a phosphorus unit, we decided to synthesize a bulky monophosphite compound by reaction of the thallium silsesquioxide $\mathbf{A}$ with dibenzo $[d, f]-3,3^{\prime}, 5,5^{\prime}$ tetra-tert-butyl[1,3,2]dioxaphosphepin chloride, yielding the desired compound $\mathbf{2}$ in high yield (Scheme 1).

The ${ }^{13} \mathrm{C}$ NMR spectrum of silsesquioxanes is known to be very indicative of the obtained purity and geometry of the product, since the ipso-carbons of the silicon organic side-groups are very sensitive to their respective environment. As expected, the ${ }^{13} \mathrm{C}$ NMR spectrum of compound 2 reflected the 1:3:3 ratio between the ipso-
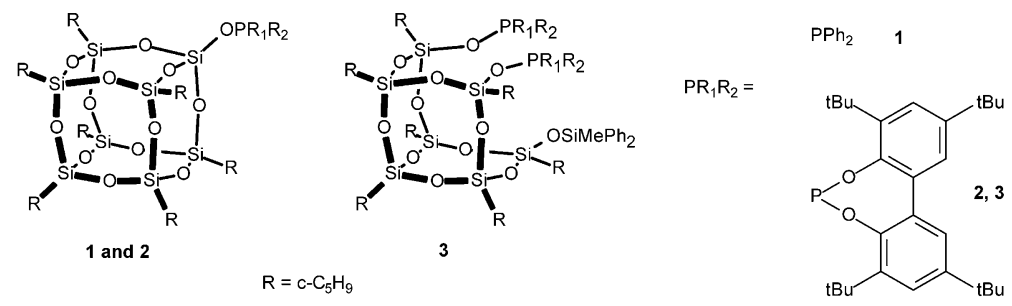

Figure 2. 


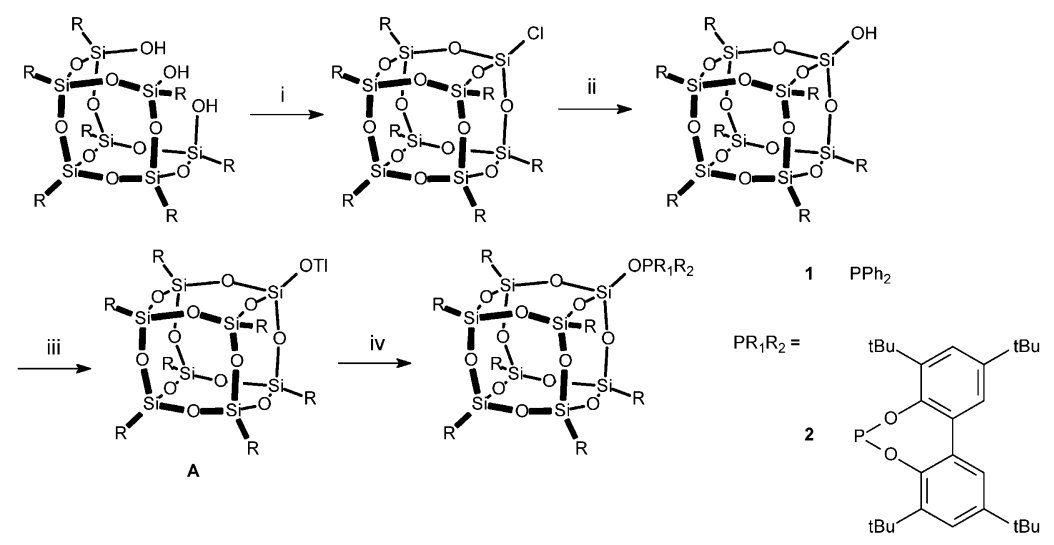

Scheme 1. Synthetic route to compounds 1 and 2: i) $\mathrm{SiCl}_{4}, 3$ equivs. $\mathrm{NEt}_{3}, \mathrm{THF}$; ii) $\mathrm{H}_{2} \mathrm{O}$; iii) $\mathrm{TlOEt}$, toluene; iv) for 1): $\mathrm{ClPPh}_{2}$, $\mathrm{NEt}_{3}$, toluene, r.t. $(16 \mathrm{~h})$; for 2): phosphorochloridite, $\mathrm{NEt}_{3}$, toluene, r.t. $(16 \mathrm{~h}) ; \mathrm{R}=c-\mathrm{C}_{5} \mathrm{H}_{9}$.

carbons of the cyclopentyl groups, indicative of a $C_{3 \mathrm{v}}$ symmetry for the obtained product. In the corresponding ${ }^{31} \mathrm{P}$ NMR spectrum a singlet was present at $\delta=$ $132.6 \mathrm{ppm}$, which is a normal chemical shift value for phosphites. Very recently, the group of Edelmann published the synthesis of a phosphorus diamide based on the same structural skeleton as present in $\mathbf{1}$ and $\mathbf{2}$, by reaction of the monosilanol shown in Scheme 1 with $\mathrm{P}\left(\mathrm{NMe}_{2}\right)_{3} \cdot{ }^{[9 \mathrm{c}]}$

For comparison with the monodentate compound based on this completely condensed thallium silsesquioxide framework, diphosphite $\mathbf{3}$ was synthesized (Scheme 2) using a similar procedure as for the diphosphinites reported previously by our group. ${ }^{[16]}$ Compound 3 was prepared in a one-step reaction in $79 \%$ yield from the incompletely condensed silsesquioxane disilanol $\left(c-\mathrm{C}_{5} \mathrm{H}_{9}\right)_{7} \mathrm{Si}_{7} \mathrm{O}_{9}(\mathrm{OH})_{2} \mathrm{OSiMePh}_{2}(\mathbf{B})$. This compound is readily available by selective monosilylation of the corresponding trisilanol $\left(c-\mathrm{C}_{5} \mathrm{H}_{9}\right)_{7} \mathrm{Si}_{7} \mathrm{O}_{9}(\mathrm{OH})_{3} \cdot{ }^{[22]}$ The $\mathrm{SiMePh}_{2}$ protecting group is used instead of the more commonly used $\mathrm{SiMe}_{3}$ unit because of crystal engineering reasons, as silsesquioxanes containing this former group have a higher tendency to crystallize. ${ }^{[23]}$ Also compound 3 was fully characterized by ${ }^{1} \mathrm{H},{ }^{13} \mathrm{C}$ and ${ }^{31} \mathrm{P}$ NMR spectroscopy as well as by elemental analysis.

In the ${ }^{13} \mathrm{CNMR}$ spectrum of compound $\mathbf{3}$, the expected $2: 2: 1: 1: 1$ ratio was observed for the signals of the ipso-carbons of the cyclopentyl groups on the silicon atoms in the silsesquioxane framework. Single crystals, suitable for X-ray analysis, were obtained by recrystallization from a hot dichloromethane/acetonitrile mixture. The molecular structure for this compound is depicted in Figure 3 together with selected bond lengths and angles.

Due to rotational freedom around the $\mathrm{P}-\mathrm{O}$ (silsesquioxane) bonds, the phosphite groups are not constrained to any particular mutual orientation. The intramolecular $\mathrm{P}-\mathrm{P}$ distance of 7.6782(8) $\AA$ in the solid state seems rather large, but coordination to transition metals in a chelating manner may still be
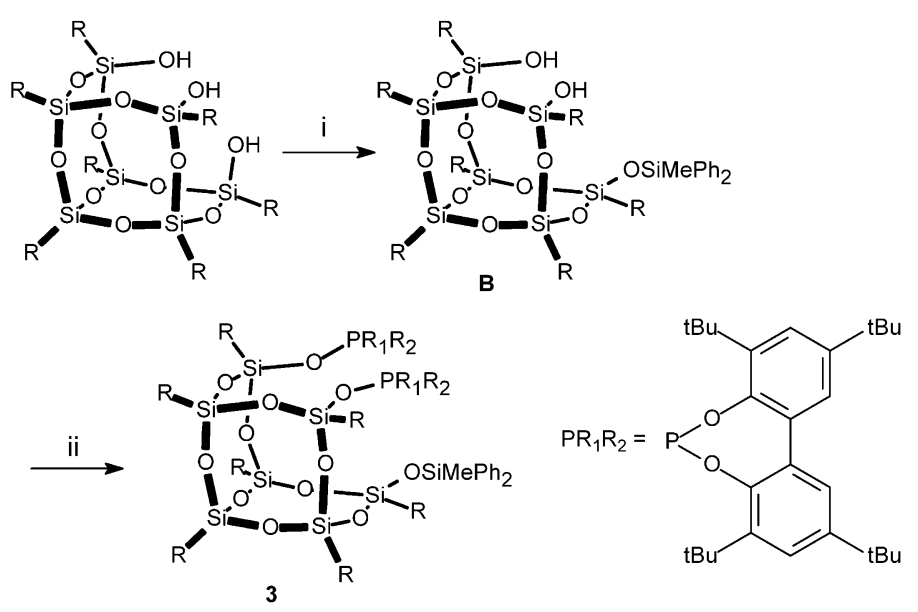

Scheme 2. Synthetic route to compound 3: i) $\mathrm{ClSiMePPh}_{2}$, $\mathrm{NEt}_{3}, \mathrm{THF}, \Delta(5 \mathrm{~min})$, r.t. $(16 \mathrm{~h})$, ii) 2 equivs. phosphorochloridite, $\mathrm{NEt}_{3}$, toluene, r.t. $(16 \mathrm{~h}) ; \mathrm{R}=c-\mathrm{C}_{5} \mathrm{H}_{9}$.

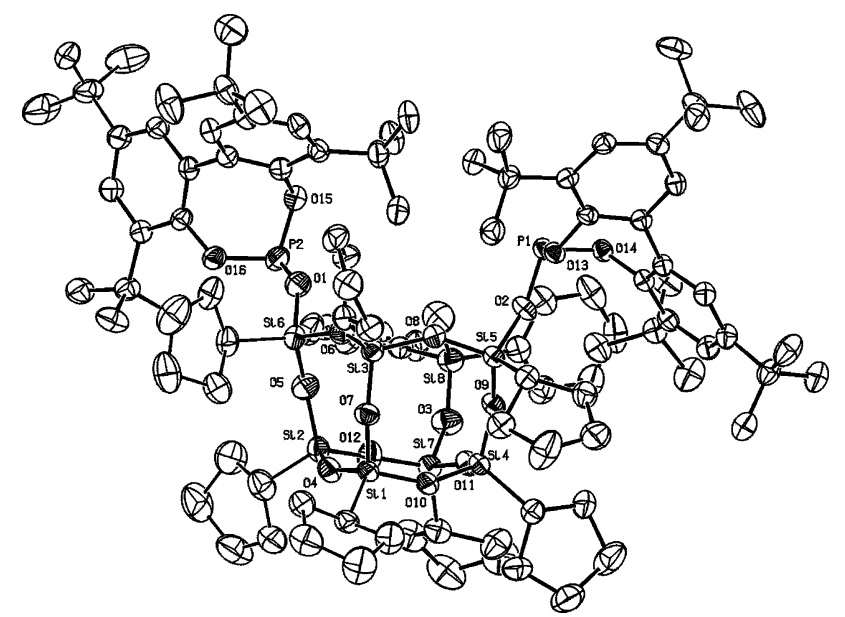

Figure 3. ORTEP representation of compound 3. Displacement ellipsoids are drawn at the $50 \%$ probability level. All hydrogens atoms are omitted for clarity. Selected bond lengths $(\AA)$ and angles $\left({ }^{\circ}\right): \mathrm{P} 1-\mathrm{O} 2$ 1.5911(18); P2-O1 1.589(2); Si5-O2 1.6404(18); Si6-O1 1.636(2); Si4-O9 1.6217(18); Si5-O9 1.6149(18); Si7-O3 1.609(3); Si8-O3 1.630(2); P1-P2 7.6782(8); Si5-O2-P1 144.11(11); Si6-O1-P2 143.17(13); Si4-O9-Si5 152.30(11); Si7-O3-Si8 150.05(14). 
possible and cannot be excluded as yet. As is normally observed for silsesquioxane framework structures the $\mathrm{Si}-\mathrm{O}-\mathrm{Si}$ bonds are slightly bent outward, with an average angle of around $150^{\circ} .{ }^{[4 a]}$ Total sums around the phosphorus atoms are $299.76^{\circ}$ for $\mathrm{P} 1$ and $298.94^{\circ}$ for $\mathrm{P} 2$. The bond lengths for the 'termina' Si5-02 and Si6-O1 bond [1.6404(18) $\AA$ and 1.636(2) $\AA$, respectively9 are slightly longer than those for the inter-framework bonds Si4-O9 and Si5-O9 of 1.6217(18) $\AA$ and 1.6149(18) $\AA$. This is an indication of the electron-withdrawing character of the silsesquioxane framework. ${ }^{[16]}$

\section{Platinum Complex 4}

Edelmann and co-workers have recently claimed the formation of a cis- $\mathrm{PtCl}_{2}(\mathrm{P})_{2}$ compound, $\mathrm{P}$ being their silsesquioxane based phosphorodiamide $\left(c-\mathrm{C}_{6} \mathrm{H}_{11}\right)_{7}$ $\mathrm{Si}_{8} \mathrm{O}_{12} \mathrm{OP}\left(\mathrm{NMe}_{2}\right)_{2} \cdot{ }^{\left[{ }^{\mathrm{c}}\right]}$ However, their conclusions were based on an incorrect interpretation of the observed coupling constant $J_{\text {Pt-P }}$ of $2730 \mathrm{~Hz}$, since such a value typically indicates a complex with both phosphorus ligands in a mutual trans fashion. ${ }^{[24]}$ Based on these findings, we decided to investigate the coordination behaviour of ligand $\mathbf{2}$ towards platinum (Scheme 3 ).

After reaction of 2 equivalents of compound 2 with $\mathrm{PtCl}_{2}$ (cod) in $\mathrm{CH}_{2} \mathrm{Cl}_{2}$ for 2 hours at room temperature and subsequent removal of the solvent, a white solid was obtained. The ${ }^{31} \mathrm{P}$ NMR spectrum showed a singlet at $\delta=80.3 \mathrm{ppm}$, together with ${ }^{195} \mathrm{Pt}$ satellites and a coupling constant $J_{\mathrm{Pt}-\mathrm{P}}$ of $4680 \mathrm{~Hz}$, which is characteristic for two phosphites coordinated in a trans-fashion. ${ }^{[24]} \mathrm{By}$ slow diffusion of $\mathrm{CH}_{3} \mathrm{CN}$ into a $\mathrm{CH}_{2} \mathrm{Cl}_{2}$ solution of this compound, single crystals could be grown that were suitable for X-ray analysis. From the crystallographic study, it is clear that this complex is indeed trans$\left[\mathrm{PtCl}_{2}(\mathbf{2})_{2}\right]$, as is evident from the molecular structure, depicted in Figure 4, together with relevant bond lengths and bond angles. It is only the second crystal structure of a monofunctionalized, completely condensed silsesquioxane framework, the first one bearing an alkyl linker instead of the oxo group. ${ }^{[25]}$
The geometry around the platinum atom in complex 4 is only slightly distorted square planar, as can be concluded from the angles $\mathrm{P} 1-\mathrm{Pt}-\mathrm{P} 2$ of $178.36(9)^{\circ}$ and $\mathrm{Cl} 1-\mathrm{Pt}-\mathrm{Cl} 2$ of $178.74(12)^{\circ}$. Both silsesquioxane groups are located on the same side of the molecule. This rather unexpected phenomenon must result from favourable packing interactions that dominate over steric constraints in the solid state configuration only. The closest intramolecular $\mathrm{Si}-\mathrm{Si}$ distance between the two silsesquioxane moieties is Si7-Si10 of 7.635(5) $\AA$. The slight distortion from ideal square planarity is also apparent from the angles $\mathrm{P} 1-\mathrm{Pt}-\mathrm{Cl} 1\left[91.00(10)^{\circ}\right]$ and $\mathrm{P} 1-\mathrm{Pt}-\mathrm{Cl} 2$ $\left[87.82(10)^{\circ}\right]$. The intramolecular $\mathrm{P}-\mathrm{P}$ distance is 4.529(4) $\AA$. The $\mathrm{Pt}-\mathrm{P}$ bond lengths [2.267(3) $\AA$ for

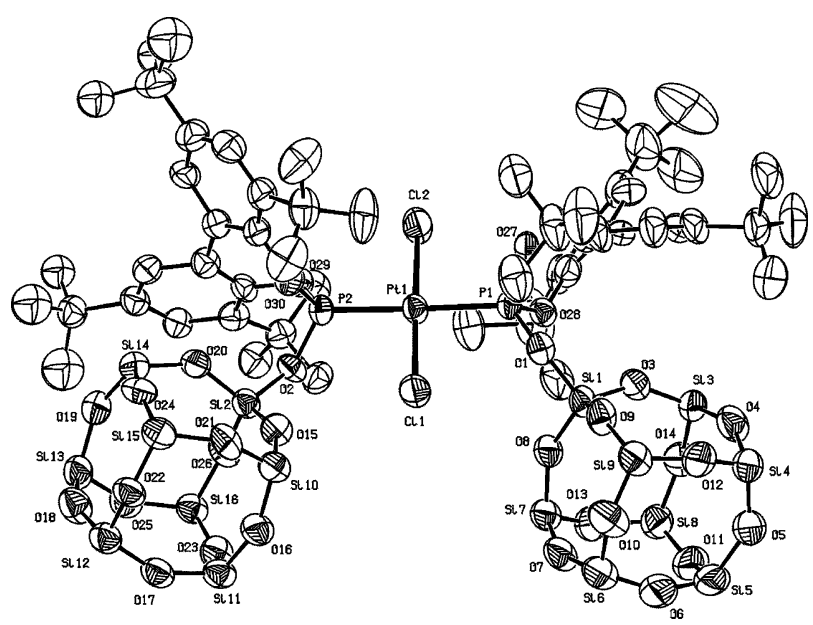

Figure 4. ORTEP representation of complex 4, trans$\left[\mathrm{PtCl}_{2}(\mathbf{2})_{2}\right]$. Displacement ellipsoids are drawn at the $50 \%$ probability level. All hydrogen atoms and all cyclopentyl substituents are omitted for clarity. Selected bond lengths ( $\AA$ ) and angles $\left(^{\circ}\right)$ : $\mathrm{Pt}-\mathrm{P} 1$ 2.267(3); $\mathrm{Pt}-\mathrm{P} 2$ 2.262(3); $\mathrm{Pt}-\mathrm{Cl} 1$ 2.279(3); Pt-Cl2 2.304(3); P1-O1 1.567(6); P2-O2 1.569(6); Si1-O1 1.635(6); Si2-O2 1.646(6); Si1-O3 1.601(7); Si2-O15 1.604(7); $\mathrm{P} 1-\mathrm{O} 27$ 1.583(7); $\mathrm{P} 1-\mathrm{O} 28$ 1.601(7); $\mathrm{P} 2-\mathrm{O} 29$ 1.581(7); $\mathrm{P} 2-\mathrm{O} 30$ 1.598(7); $\mathrm{P} 1-\mathrm{P} 2$ 4.529(4); $\mathrm{Cl} 1-\mathrm{Pt}-\mathrm{Cl} 2$ 178.74(12); P1-Pt-P2 178.36(9); P1-Pt-Cl1 91.00(10); $\mathrm{P} 1-\mathrm{Pt}-\mathrm{Cl} 2 \quad 87.82(10) ; \quad \mathrm{P} 2-\mathrm{Pt}-\mathrm{Cl} 1 \quad 90.31(10) ; \quad \mathrm{P} 2-\mathrm{Pt}-\mathrm{Cl} 2$ 90.87(10); $\quad \mathrm{Si1}-\mathrm{O} 1-\mathrm{P} 1 \quad 139.6(4) ; \quad \mathrm{Si} 2-\mathrm{O} 2-\mathrm{P} 2 \quad 141.4(4)$; $\mathrm{Pt}-\mathrm{P} 1-\mathrm{O} 1 \quad 118.4(3) ; \quad \mathrm{Pt}-\mathrm{P} 2-\mathrm{O} 2 \quad 117.4(3) ; \quad \mathrm{Si} 1-\mathrm{O} 3-\mathrm{Si} 3$ 145.3(4); Si2-O15-Si10 150.2(5).
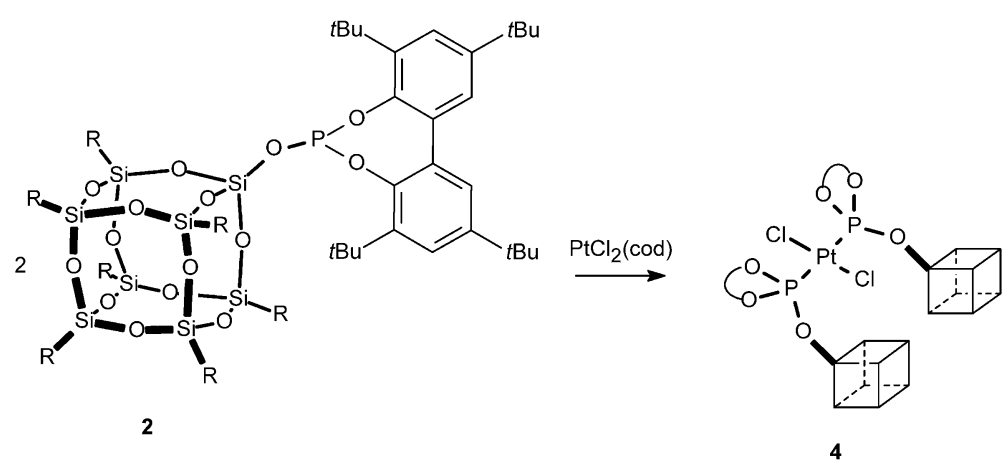

Scheme 3. Reaction of compound 2 with $\mathrm{PtCl}_{2}(\mathrm{cod})$ to form complex $\mathbf{4}$, trans- $\left[\mathrm{PtCl}_{2}(\mathbf{2})_{2}\right]$. 
$\mathrm{Pt}-\mathrm{P} 1$ and $2.262(3) \AA$ for $\mathrm{Pt}-\mathrm{P} 2]$ are slightly but significantly longer than for other platinum-phosphite complexes reported in the literature, while the $\mathrm{Pt}-\mathrm{Cl}$ bond lengths [2.279(3) $\AA$ for $\mathrm{Pt}-\mathrm{Cl} 1$ and 2.304(3) $\AA$ for $\mathrm{Pt}-\mathrm{Cl} 2)$ on the contrary are somewhat elongated in comparison with these reference compounds. ${ }^{[26]}$ This is a clear indication of the electron-withdrawing character of the silsesquioxane framework.

To evaluate whether the diphosphite $\mathbf{3}$, with the sterically constrained 1,1'-biphenyldioxaphosphepin substituents, would show a different coordination behaviour in comparison to the previously reported diphosphinite compound $\left(c-\mathrm{C}_{5} \mathrm{H}_{9}\right)_{7} \mathrm{Si}_{7} \mathrm{O}_{9}(\mathrm{OPPh})_{2}$ OSiMePh ${ }_{2}{ }^{[16]}$ complexation reactions were carried out with palladium, molybdenum and rhodium precursors.

\section{Palladium Complex 5}

Complexation of 3 with $\mathrm{PdCl}_{2}(\mathrm{cod})$ at room temperature resulted in a fine yellow powder and the ${ }^{31} \mathrm{P}$ NMR spectrum showed a singlet at $\delta=88.9 \mathrm{ppm}$ (Scheme 4). From this finding alone, no conclusion can be drawn as to which isomer is formed. There is no general relationship for the chemical shifts of either cis or trans (palladium) complexes, to validate the mode of coordination of the bidentate ligand, on the basis of the position of the NMR signal alone. In order to deduce the exact configuration of complex $\mathbf{5}$, a crystallographic study was carried out on single crystals obtained from slow diffusion of acetonitrile into a dichloromethane solution of $\mathrm{PdCl}_{2}(\mathbf{2})$. The molecular structure for complex $\mathbf{5}$ is depicted in Figure 5.

The molecular structure shows that the palladium atom of complex $\mathbf{5}$ is in a square planar coordination. In contrast to our earlier studies with the diphosphinite equivalent where we obtained only the cis-isomer, ${ }^{[16]}$ in the present complex the phosphite units are in a mutual trans relationship, giving rise to a bite angle for the diphosphite ligand $\mathrm{P} 1-\mathrm{Pd}-\mathrm{P} 2$ of $171.45(5)^{\circ}$ while the Cl1- $\mathrm{Pd}-\mathrm{Cl} 2$ angle is $171.55(4)^{\circ}$. The $\mathrm{P}-\mathrm{Pd}-\mathrm{Cl}$ angles correspond to $85.12(4)^{\circ}$ and $90.41(4)^{\circ}$. To date, characterization of palladium-diphosphite complexes by X-ray analysis has been rare. The $\mathrm{Pd}-\mathrm{P}$ bond lengths of 2.2859(12) $\AA(\mathrm{Pd}-\mathrm{P} 1)$ and 2.2821(10) $\AA\left(\mathrm{Pd}-\mathrm{P}_{2}\right)$ as well as the $\mathrm{Pd}-\mathrm{Cl}$ bond lengths of $2.2980(13) \AA(\mathrm{Pd}-\mathrm{Cl} 1)$

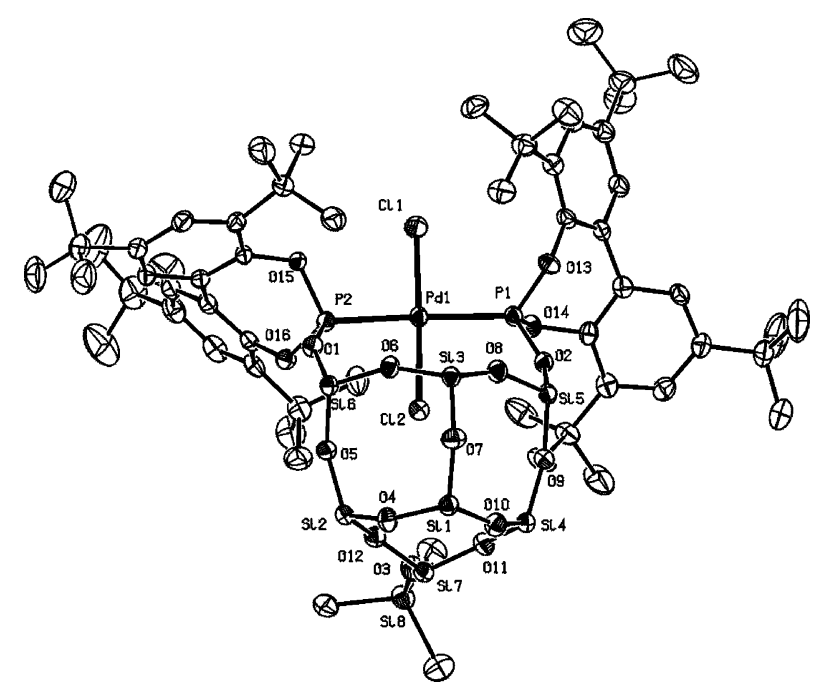

Figure 5. ORTEP representation of complex 5, trans$\left[\mathrm{PdCl}_{2}(\mathbf{3})\right]$. Displacement ellipsoids are drawn at the $50 \%$ probability level. All hydrogen atoms, cyclopentyl sidegroups and solvent molecules are omitted for clarity. Selected bond lengths $(\AA)$ and angles $\left(^{\circ}\right)$ : $\mathrm{Pd}-\mathrm{P} 1$ 2.2859(12); Pd-P2 2.2821(10); Pd-Cl1 2.2980(13); Pd-Cl2 2.2924(13); P1-O2 1.560(3); P2-O1 1.560(3); Si5-O2 1.654(3); Si6-O1 1.654(3); Si4-O9 1.623(3); Si5-O9 1.603(3); Si7-O3 1.610(3); Si8-O3 1.633(3); $\mathrm{P} 1-\mathrm{P} 2 \quad 4.5554(15) ; \quad \mathrm{Cl} 1-\mathrm{Pd}-\mathrm{Cl} 2$ 171.55(4); P1-Pd-P2 171.45(5); Cl1-Pd-P1 90.41(4); Cl2-Pd-P2 85.12(4;) P1-Pd-Cl2 90.69(4); P2-Pd-Cl1 94.82(5); $\mathrm{Si} 5-\mathrm{O} 2-\mathrm{P} 1 \quad 144.9(2) ; \quad \mathrm{Si} 6-\mathrm{O} 1-\mathrm{P} 2 \quad 151.3(2) ; \quad \mathrm{Pd}-\mathrm{P} 1-\mathrm{O} 2$ 115.98(12); Pd-P2-O1 112.63(11); Si4-O9-Si5 154.7(2); Si7-O3-Si8 152.0(2).

2.2924(13) ^ $(\mathrm{Pd}-\mathrm{Cl} 2)$ correspond well with other complexes with (bulky) diphosphite structures. ${ }^{[27]}$ Dehnicke has reported on the synthesis and X-ray structural analysis of $\mathrm{PdCl}_{2}\left\{\mathrm{P}\left(\mathrm{OSiMe}_{3}\right)_{3}\right\}$. The $\mathrm{Pd}-\mathrm{P}[2.229(1) \AA]$, $\mathrm{Pd}-\mathrm{Cl}[2.342(2) \AA]$ and $\mathrm{P}-\mathrm{O}[1.543(3) \AA]$ bond lengths are all comparable. ${ }^{[28]}$ The various bond lengths and bond angles for the silsesquioxane framework are in the normal ranges with little difference to the case of free ligand $\mathbf{3}$ (vide supra).

\section{Molybdenum Complex 6}

To examine if bidentate coordination in a cis-fashion is allowed for with this sterically congested diphosphite
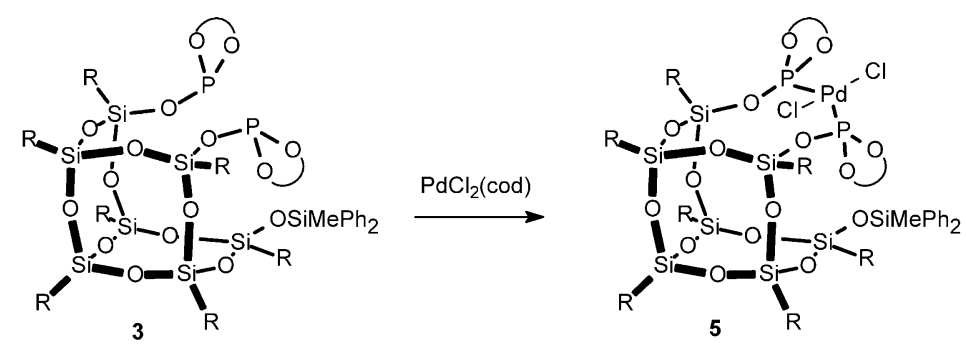

Scheme 4. 


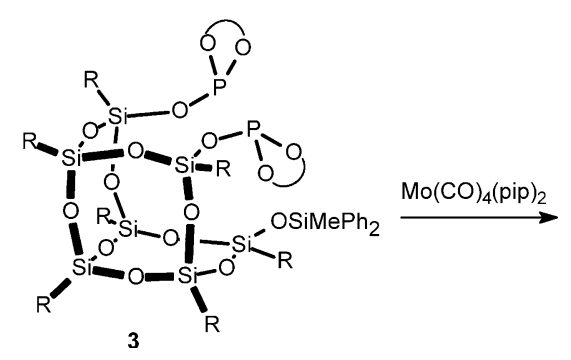

Scheme 5.

ligand, $\mathrm{Mo}(\mathrm{CO})_{4}(\mathrm{pip})_{2}(\mathrm{pip}=$ piperidine $)$ was reacted with a small excess of ligand $\mathbf{3}$ in dichloromethane for 4 hours at room temperature (Scheme 5). From the concentrated solution a white powder, complex $\mathbf{6}$, was obtained after addition of acetonitrile.

The FT-IR spectrum of $\mathbf{6}$ showed four absorption bands in the carbonyl region, at 2041.3, 1947.9, 1935.2 and $1922.3 \mathrm{~cm}^{-1}$. These values agree reasonably well with other cis-Mo( $(\mathrm{CO})_{4}(\text { phosphite })_{2}$ complexes. ${ }^{[29,30]}$ In the ${ }^{31} \mathrm{P}$ NMR spectrum of the crude reaction mixture a singlet was observed at $\delta=149.6 \mathrm{ppm}$ together with a minor peak at $\delta=131.3$ ppm indicating the small excess of free ligand. To get a confirmation of the actual coordination of the ligand to the molybdenum atom, a crystallographic study was undertaken, since single crystals could be grown by slow diffusion of acetonitrile into a dichloromethane solution of $\mathrm{Mo}(\mathrm{CO})_{4}(3)$. The molecular structure, as determined by X-ray diffraction, is depicted in Figure 6. To date, the number of X-ray structures, found in the Cambridge Crystallographic Database, for other $\mathrm{Mo}(\mathrm{CO})_{4}-(\mathrm{di})$ phosphite complexes is limited to thirteen, of which only four contain $\mathrm{P}(\mathrm{OR})(\mathrm{OAr})_{2}$ moieties, $(\mathrm{Ar}=$ any aryl group, $\mathrm{R}=$ any non-aryl related substituent).

The geometry around the molybdenum atom of complex $\mathbf{6}$ is distorted octahedral. In agreement with the IR spectrum measured, the ligand coordinates in a bidentate manner to the molybdenum atom, adopting a cis-conformation. This means however, that there is significant crowding around the center of the molecule, with the dioxaphosphepin moieties repositioned at the far sides of the molecule. The bite angle $\mathrm{P} 1-\mathrm{Mo}-\mathrm{P} 2$ is 99.67(3) ${ }^{\circ}$, which causes the $\mathrm{C} 107-\mathrm{Mo}-\mathrm{C} 108$ angle to become as small as $82.00(16)^{\circ}$. This bite angle is significantly larger than the ideal $90^{\circ}$ for a true ciscoordination, most likely due to steric constraints of the phosphite moieties. The geometry around the Mo in the equatorial plane (Mo-P1-P2-C107-C108) is slightly deviated from-planarity, as evidenced by the angles C108-Mo-P1 of $169.69(13)^{\circ}$ and $\mathrm{C} 107-\mathrm{Mo}-\mathrm{P} 2$ of $171.76(11)^{\circ}$, leading to a dihedral angle between the $\mathrm{Mo}-\mathrm{P} 1-\mathrm{P} 2$ plane and the $\mathrm{Mo}-\mathrm{C} 107-\mathrm{C} 108$ plane of $3.4^{\circ}$. The CO ligands in the axial positions deviate from the ideal plane because the $\mathrm{C} 105-\mathrm{Mo}-\mathrm{C} 106$ angle is only $171.76(11)^{\circ}$. This distortion is significantly larger than those found for $c i s-\left[\mathrm{Mo}(\mathrm{CO})_{4}\left(\mathrm{P}(\mathrm{OPh})_{3}\right)_{2}\right]$ for which an angle $\mathrm{C}_{\mathrm{ax}}-\mathrm{Mo}-\mathrm{C}_{\mathrm{ax}}$ of $175.5(2)^{\circ}$ was reported. ${ }^{[31]}$ The

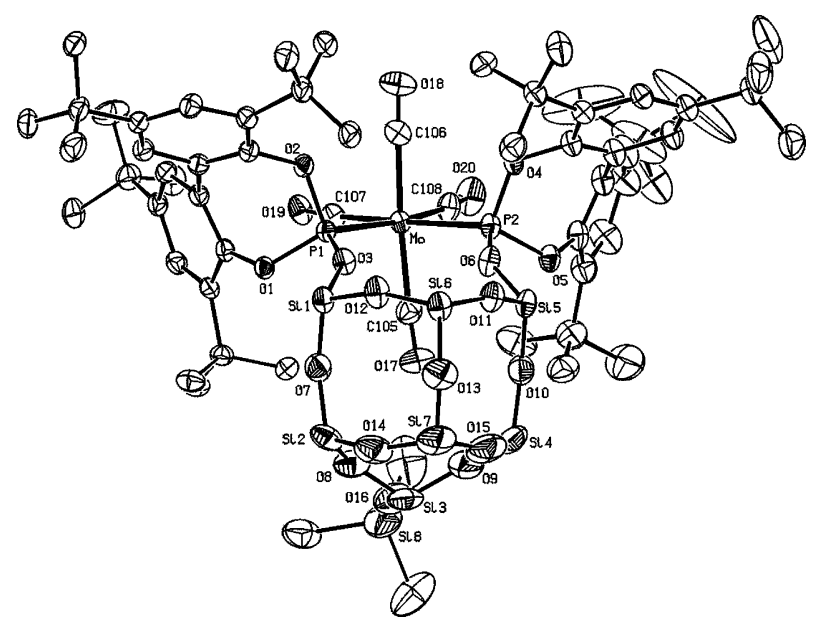

Figure 6. ORTEP representation of complex 6, cis$\left[\mathrm{Mo}(\mathrm{CO})_{4}(3)\right]$. Displacement ellipsoids are drawn at the $50 \%$ probability level. All hydrogen atoms, cyclopentyl sidegroups and solvent molecules are omitted for clarity. Selected bond lengths $(\AA)$ and angles $\left(^{\circ}\right)$ : Mo-P1 2.4771(10); Mo-P2 2.4509(10); Mo-C105 2.0471(5); Mo-C106 2.050(4); Mo-C107 2.023(4); Mo-C108 2.009(4); C-O 1.13-1.15; P1-O3 1.574(3); P2-O6 1.575(3); Si1-O3 1.653(3); Si5-O6 1.650(3); Si5-O10 1.614(3); Si4-O10 1.627(4); Si3-O16 1.615(5); Si8-O16 1.628(5); P1-P2 3.7661(14); P1-Mo-P2 99.67(3); C107-Mo-C108 82.00(16); C105-Mo-C106 171.07(16); C108Mo-P1 169.69(13); C107-Mo-P2 171.76(11); P1-Mo-C105 88.99(11); P2-Mo-C106 89.77(12); P1-Mo-C106 87.90(11); $\mathrm{P} 2-\mathrm{Mo}-\mathrm{C} 105 \quad 83.09(12) ; \quad \mathrm{Mo}-\mathrm{C} 107-\mathrm{O} 13 \quad$ 173.62(17); Mo-C105-O14 176.61(19); Mo-P1-O3 119.14(11); Mo-P2-O6 118.35(11); P1-O3-Si1 147.62(19); P2-O6-Si5 146.0(2); Si5-O10-Si4 150.3(2); Si3-O16-Si8 161.4(3).

Mo-P bond lengths of 2.4771(10) $\AA$ (Mo-P1) and $2.4509(10) \AA(\mathrm{Mo}-\mathrm{P} 2)$ are in good agreement with the structures reported by Gray et al. ${ }^{[29,32]}$ and by Kee and co-workers ${ }^{[30]}$ on Mo complexes containing silyldiphosphites. The phosphorus-oxygen bond lengths of 1.574(3) $\AA$ for $\mathrm{P} 1-\mathrm{O} 3$ and $1.575(3) \AA$ for $\mathrm{P} 2-\mathrm{O} 6$ are slightly shorter than in the silylphosphite systems (generally above $1.60 \AA$ ). These latter ligands are structurally identical to a compound used by Pringle. ${ }^{[33]}$ This implies that the $\mathrm{P}-\mathrm{O}-\mathrm{Si}$ angles found in complex $6, \mathrm{P} 1-\mathrm{O} 3-\mathrm{Si} 1$ at $147.62(19)^{\circ}$ and $\mathrm{P} 2-\mathrm{O}^{-}-\mathrm{Si} 5$ at $146.0(2)^{\circ}$, are considerably larger than found in the literature, where the $\mathrm{P}-\mathrm{O}-\mathrm{Si}$ angles are in between $129.9^{\circ}$ and $138.5^{\circ}$. Compared to the Mo complex described by Kee et al., the difference is even larger, since the $\mathrm{P}-\mathrm{O}-\mathrm{Si}$ angles within the silyltriphosphite $\mathrm{SiR}(\mathrm{OP})_{3}$ are around $124-$ $125^{\circ} \cdot[30 \mathrm{c}]$

\section{Rhodium Complex 7}

The completely different coordination behaviour of ligand 3 in Pd complex 5 and Mo complex 6 indicates a high level of flexibility in the chelate ring of this 
diphosphite. We were therefore interested to study the coordination with a third metal species, the rhodium dimer $\left[\mathrm{Rh}(\mu-\mathrm{Cl})(\mathrm{CO})_{2}\right]_{2}$. As we $\mathrm{e}^{[16,34,35]}$ and others ${ }^{[36]}$ have previously reported, the corresponding $\mathrm{RhCl}(\mathrm{CO})(\mathrm{P})_{2^{-}}$ complexes normally exhibit trans-coordination of two phosphorus moieties, although some cis complexes have also been described. ${ }^{[37]}$ Upon reaction of 2 equivalents of 3 with 1 equivalent of this rhodium precursor in refluxing toluene overnight and subsequent removal of the solvent a yellow-brown solid was obtained. The ${ }^{31} \mathrm{P}$ NMR spectrum showed the presence of two products, both doublets, and no signal of uncoordinated or decomposed ligand. The major product ( $\sim 90 \%$ by integration) appeared at $\delta=111.9 \mathrm{ppm}$ and is assigned to trans-[ $\operatorname{RhCl}(\mathrm{CO})(3)]$. The value of the coupling constant $J_{\mathrm{Rh}-\mathrm{P}}$ of $278 \mathrm{~Hz}$ is typical for Rh-phosphite complexes. ${ }^{[38]}$ Besides, a minor product at $\delta=120.9 \mathrm{ppm}$ was present, with a coupling constant $J_{\mathrm{Rh}-\mathrm{P}}$ of $217 \mathrm{~Hz}$. The IR spectrum of the solid showed two CO stretch vibrations at 2019 and $2009 \mathrm{~cm}^{-1}$. As with other literature references on this point, this complex was measured in dichloromethane and not as a powder. To interpret the spectroscopic data correctly, a crystallographic study was performed on single crystals, grown by slow diffusion of acetonitrile into a concentrated $\mathrm{CH}_{2} \mathrm{Cl}_{2}$ solution of the product. The molecular structure of this species, complex 7, is depicted in Figure 7, together with selected bond lengths and angles.

Complex $\mathbf{7}$ is a rhodium dimer, with the two phosphite moieties of the ligand spanning the dinuclear metal center. There is one terminal CO molecule present per rhodium atom, with two bridging chlorine atoms. The two phosphorus atoms are mutually cis to one another. This structure is in agreement with the two observed CO bands in the IR spectrum. This is due to the distortion of the $\mathrm{Rh} 1-\mathrm{Cl} 1-\mathrm{Rh} 2-\mathrm{Cl} 2$ plane, leading to a so-called 'butterfly - angle $\eta$ between the $\mathrm{Cl} 1-\mathrm{Rh} 1-\mathrm{Cl} 2$ plane and the $\mathrm{Cl} 1-\mathrm{Rh} 2-\mathrm{Cl} 2$ plane of $20.5^{\circ}$. This existence of two vibrations was already observed by the group of Poilblanc. ${ }^{[39]}$ Since no uncoordinated ligand was detected after reaction, complex 7 represents the minor species observed in the ${ }^{31} \mathrm{P}$ NMR spectrum. The geometry around each rhodium atom is square planar, with the $\mathrm{P} 1-\mathrm{Rh}-\mathrm{P} 2$ angles at $177.70(3)^{\circ}$ and $176.82(3)^{\circ}$. These features of the molecular structure of complex 7 are especially visible from a side-view, as presented in Figure 8.

The skeletal core of the molecule, not regarding any cyclopentyl groups or the biphenyl derivatives on the phosphorus atoms, has a high degree of symmetry. The $\mathrm{Cl1}-\mathrm{Rh}-C$ angles are nearly identical at $176.58(10)^{\circ}$ and $177.58(11)^{\circ}$. The $\mathrm{Rh}-\mathrm{P}$ bond lengths are around $2.18 \AA$, while the $\mathrm{Rh}-C$ and $\mathrm{Rh}-\mathrm{Cl}$ lengths are around $1.80-$ $1.81 \AA$ and $2.41-2.42 \AA$, respectively. All these data compare well with the values found in the mononuclear complex $\left[\mathrm{RhCl}(\mathrm{CO})\left\{\mathrm{P}(\mathrm{OPh})_{3}\right\}_{2}\right]^{[40]}$ with the exception of the Rh-P bonds, which are around $\sim 0.1 \AA$ shorter in

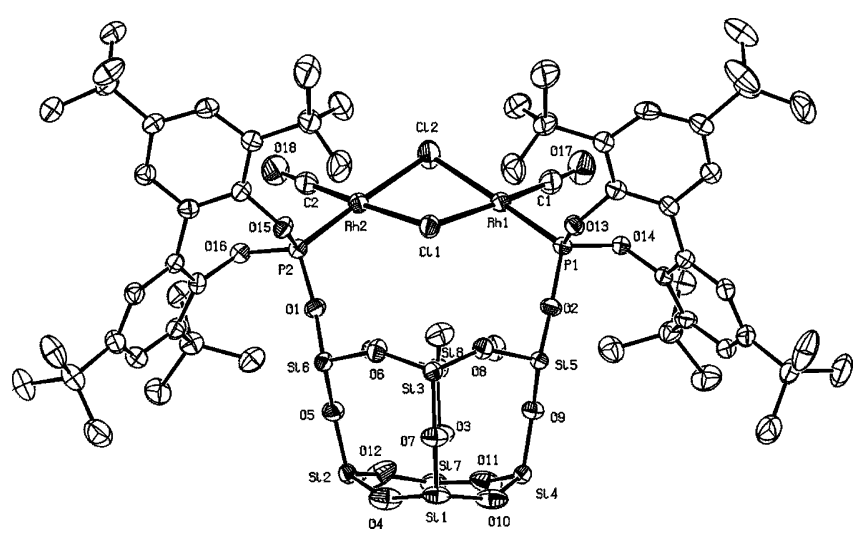

Figure 7. ORTEP representation of complex 7, $[\{\mathrm{Rh}(\mu-\mathrm{Cl})$ $\left.(\mathrm{CO})\}_{2}\left(\kappa^{2}-3\right)\right]$. Displacement ellipsoids are drawn at the $50 \%$ probability level. All hydrogens atoms and cyclopentyl sidegroups omitted for clarity. Selected bond lengths (A) and angles $\left({ }^{\circ}\right)$ : Rh1-P1 2.1820(8); Rh2-P2 2.1768(8); Rh1-Cl1 2.4135(8); Rh1-Cl2 2.4213(10); Rh2-Cl1 2.4179(9); Rh2-Cl2 2.4154(10); Rh1-C1 1.809(3); Rh2-C2 1.814(3); C1-O17 1.155(4); C2-O18 1.140(4); P1-O2 1.563(2); P2-O1 1.564(2); $\quad \mathrm{Si5}-\mathrm{O} 2$ 1.650(2); $\mathrm{Si6}-\mathrm{O} 1$ 1.652(2); Si4-O9 1.630(2); Si5-O9 1.619(2); Si7-O3 1.612(2); Si8-O3 1.643(2); P1-P2 6.5417(14); Rh1-Rh2 3.5163(5); P1-Rh1-Cl2 177.70(3); P2-Rh2-Cl2 176.82(3); Cl1-Rh1-C1 176.58(10); Cl1-Rh2-C2 177.58(11); P1-Rh1-Cl1 93.51(3); P2-Rh2-Cl1 92.65(3); C1-Rh1-Cl2 92.41(10); C2-Rh2-Cl2 93.50(10); Cl1-Rh1-Cl2 84.18(3); Cl1-Rh2-Cl2 84.22(3); P1-Rh1-C1 89.90(10); P2-Rh2-C2 89.64(10); Rh1-Cl1-Rh2 93.40(3); Rh1-Cl2-Rh2 93.27(4); Si5-O2-P1 156.62(14); Si6-O1-P2 155.57(15); Rh1-P1-O2

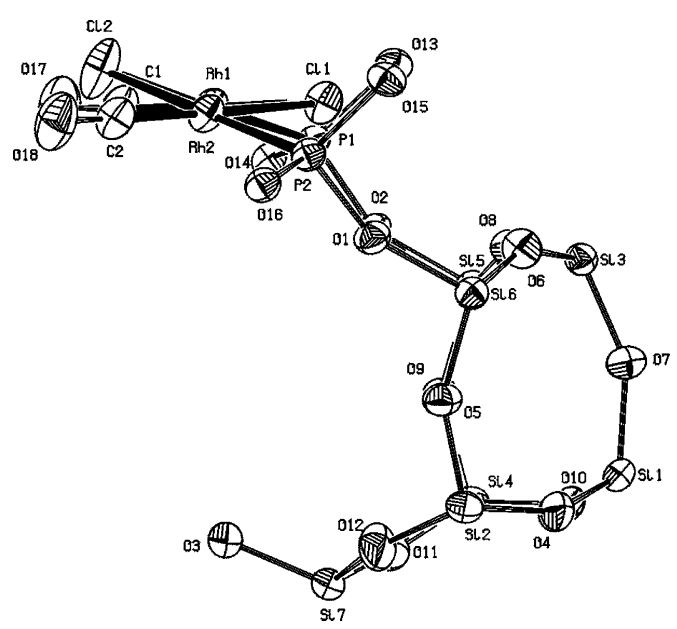

Figure 8. Side view of complex 7, showing the symmetry of the rhodium atoms in the dimeric species and the butterfly shape of the Cl1-Rh1-Cl2-Rh2 cycle.

complex 7. The $\mathrm{Rh}-\mathrm{Cl}$ bond lengths are slightly elongated in comparison to the value $[2.370(3) \AA]$ for the terminal $\mathrm{Cl}$ in $\left[\mathrm{RhCl}(\mathrm{CO})\left\{\mathrm{P}(\mathrm{OPh})_{3}\right\}_{2}\right]$. The intramolecular Rh1-Rh2 distance is $3.5163 \AA$, which might 
indicate a weak metal-metal interaction. The geometry around each phosphorus atom is tetrahedral, as indicated by the angles Rh1-P1-O2 of $115.89(8)^{\circ}$ and Rh2-P2-O1 of $114.10(8)^{\circ}$.

Two other dinuclear rhodium-phosphite complexes with a similar conformation have been characterized by $\mathrm{X}$-ray crystallography. Cobley et al. have described the reaction of a calixarene based monophosphite with $\left[\mathrm{RhCl}(\mathrm{CO})_{2}\right]_{2}$ at different stoichiometries, always ending up with a mixture of two complexes in the ratio 1 to 4 , based on the ${ }^{31} \mathrm{P}$ NMR spectrum. ${ }^{[41]}$ The authors proposed an equilibrium between the trans and cis-isomer. The only product obtained as crystals turned out to be the cis-isomer. The existence of such an equilibrium in solution between the two isomers was also proposed by Poilblanc for other dinuclear rhodium phosphite complexes. ${ }^{[39]}$ Furthermore, Gavrilov and co-workers have published a similar structural motif, employing a catechol-based monophosphite. The $\mathrm{Rh}-\mathrm{Cl}$ bond lengths were around $2.40 \AA$, the $\mathrm{Rh}-\mathrm{P}$ bond lengths around $2.15 \AA .{ }^{[42]}$ Tilley recently reported on a rhodium dimer with two ligand molecules present, together with two bridging $\mathrm{Cl}$ atoms, originating from the rhodium precursor $\mathrm{RhCl}_{2}(\mathrm{cod})_{2} \cdot{ }^{[43]}$ Similar bond lengths as in complex 7 are found for these structures, especially the $\mathrm{Rh}-\mathrm{P}$ bond length and $\mathrm{Rh}-\mathrm{Rh}$ distance.

\section{Hydroformylation of 1-Octene}

Since previously reported (di)phosphites have proven to be valuable ligands for the rhodium-catalyzed hydroformylation (vide supra), we decided to use this reaction to test the potential application of ligands $\mathbf{1}$ and $\mathbf{2}$ in homogeneous catalysis. The hydroformylation of 1octene was carried out with $\mathrm{Rh}(\mathrm{acac})(\mathrm{CO})_{2}$ as the precursor. Because of the often deleterious effect of chlorides on catalytic activity, an $\mathrm{RhCl}(\mathrm{CO})$ complex is less suitable as catalyst precursor. Standard reaction conditions of 20 bar of syngas $\left(\mathrm{CO} / \mathrm{H}_{2}=1 / 1\right)$, a catalyst preformation time of 1 hour and a reaction temperature of $80^{\circ} \mathrm{C}$ were used (Scheme 6). Results of these catalytic tests with both ligands $\mathbf{2}$ and $\mathbf{3}$ are summarized in Table 1.

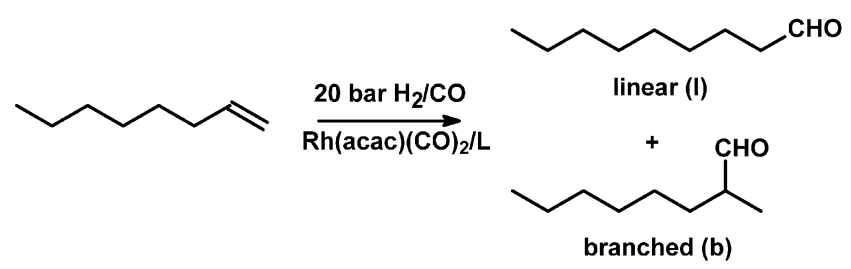

Scheme 6.

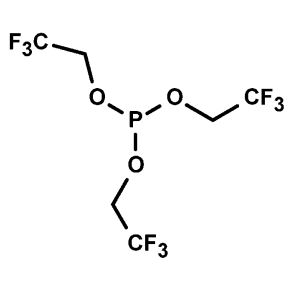

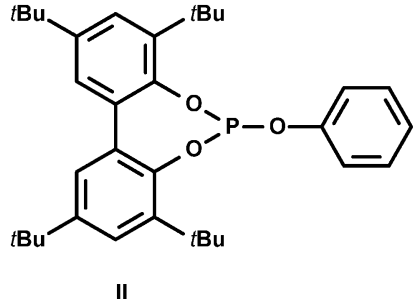

Figure 9.

With the monophosphite $\mathbf{2}$, a high activity is achieved (entry 1), with an initial turnover frequency of around $5100 \mathrm{~h}^{-1}$. In addition, an influence of the ligand to metal ratio on the catalytic performance was observed. While increasing this ratio from 5 to 10 , the activity was also increased by $33 \%$ to a turnover frequency of $6800 \mathrm{~h}^{-1}$ (entry 2). This activity is an order higher as observed with catalysts based on electron-withdrawing monophosphites such as the ligand $\mathrm{P}\left(\mathrm{OCH}_{2} \mathrm{CF}_{3}\right)_{3}$ (I). ${ }^{[13]}$ However, it does not compete yet with the sterically constrained ligand (II) in terms of activity (Figure 9). ${ }^{[18 b]}$

The regioselectivity remained low, as expected for a monodentate ligand, with an $\mathrm{l} / \mathrm{b}$ ratio of around 2.2 . With the bidentate ligand $\mathbf{3}$, a significantly lower activity is observed (entry 3 ). This is expected for such a sterically constrained chelating ligand, yet the regioselectivity remains low, which might be related to too much steric crowding around the metal centre, leading to an unselective catalyst and a low activity.

\section{Conclusions}

The synthesis of a monodentate phosphinite $\mathbf{1}$ and phosphite $\mathbf{2}$ as well as the bidentate phosphite com-

Table 1. Rhodium-catalyzed hydroformylation of 1-octene using ligands 2 and 3. ${ }^{\text {[a] }}$

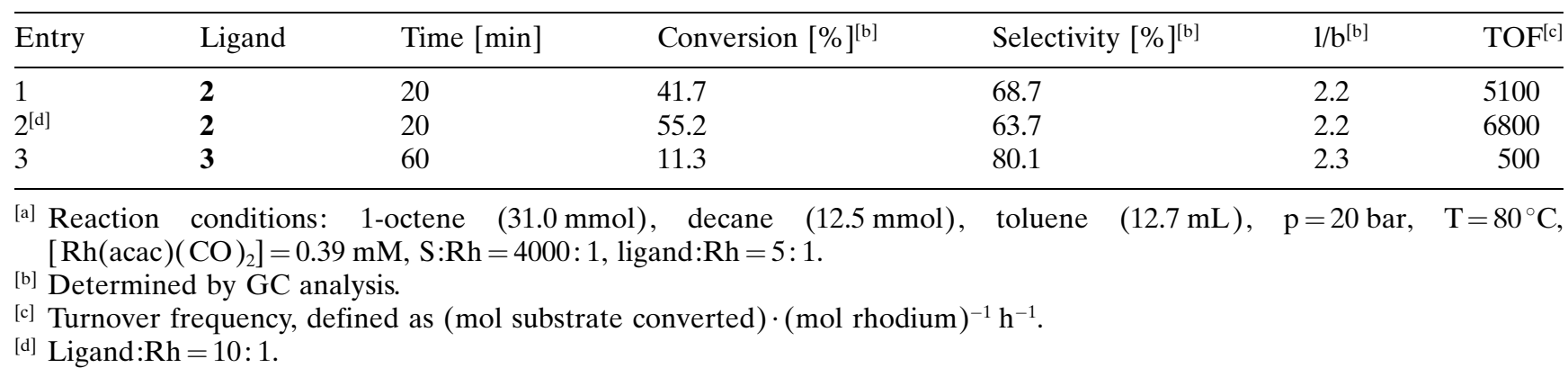


pound $\mathbf{3}$, all based on stable silsesquioxane frameworks, has been described. The coordination chemistry with the bidentate ligand 3 proved very interesting, as indicated by the molecular structures obtained for the palladium, platinum, molybdenum and rhodium complexes. Various modes of coordination, including cis, trans and a bridged dimer, were determined. This can be rationalized in terms of steric crowding and an intrinsic large flexibility range for the silyloxy-functionalized ligands. In the rhodium-catalyzed hydroformylation of 1-octene, high activities were obtained for the catalyst containing ligand 2. We believe that the structural diversity of silsesquioxanes together with their unique properties may offer many new possibilities for the development of new versatile families of phosphorus ligands, with additional new opportunities for catalyst immobilization and recycling.

\section{Experimental Section}

\section{General Remarks}

Chemicals were purchased from Aldrich, Acros or Merck and used as received. All preparations were carried out under an argon atmosphere using standard Schlenk techniques. Solvents were distilled from sodium/benzophenone (THF, ether, toluene and hexanes) or calcium hydride $\left(\mathrm{CH}_{2} \mathrm{Cl}_{2}\right.$ and $\left.\mathrm{CDCl}_{3}\right)$ prior to use. All glassware was dried by heating under vacuum.

The NMR spectra were recorded on a Varian Mercury 400 spectrometer, referenced to deuterated solvent $\left({ }^{1} \mathrm{H},{ }^{13} \mathrm{C}\left\{{ }^{1} \mathrm{H}\right\}\right)$ or $85 \% \mathrm{H}_{3} \mathrm{PO}_{4}\left({ }^{31} \mathrm{P}\left\{{ }^{1} \mathrm{H}\right\}\right)$ and chemical shifts are given in ppm. GC analyses were performed on a Shimadzu 17A chromatograph equipped with a $50 \mathrm{~m}$ PONA column. Elemental analysis was performed by Kolbe Mikroanalytisches Laboratorium, Germany. IR spectra were taken on an AVATAR E.S.P. 360 FTIR spectrometer. Dibenzo $[d, f]-3,3^{\prime}, 5,5^{\prime}$-tetratert-butyl-[1,3,2]dioxaphosphepin $P$-chloride ${ }^{[44]}$ as well as the metal precursors $\mathrm{PdCl}_{2}(\mathrm{cod}),{ }^{[45]}$ and $\mathrm{Mo}(\mathrm{CO})_{4}(\text { pip })_{2}{ }^{[46]}$ were prepared according to literature procedures. Also (c$\left.\mathrm{C}_{5} \mathrm{H}_{9}\right)_{7} \mathrm{Si}_{8} \mathrm{O}_{13} \mathrm{Tl}(\mathbf{A})$ and $\left(c-\mathrm{C}_{5} \mathrm{H}_{9}\right)_{7} \mathrm{Si}_{7} \mathrm{O}_{9}(\mathrm{OH})_{2}\left(\mathrm{OSiMePh}_{2}\right)(\mathbf{B})$ were prepared according to literature procedures. ${ }^{[21,22]}$

CAUTION: Thallium-containing compounds are poisonous. Handling of such compounds should be done with utmost care, also regarding the waste disposal of thallium-containing compounds.

\section{$\left(c-\mathrm{C}_{5} \mathrm{H}_{9}\right)_{7} \mathrm{Si}_{8} \mathbf{O}_{12} \mathrm{OPPh}_{2}(\mathbf{1})$}

$\left(c-\mathrm{C}_{5} \mathrm{H}_{9}\right)_{7} \mathrm{Si}_{8} \mathrm{O}_{12}(\mathrm{OTl})(0.42 \mathrm{~g}, 0.37 \mathrm{mmol})$ was dissolved under heating in $20 \mathrm{~mL}$ toluene giving a colloidal white solution. $\mathrm{ClPPh}_{2}(0.08 \mathrm{~g}, 0.37 \mathrm{mmol})$ was dissolved in $4 \mathrm{~mL}$ hexanes and this solution was added dropwise to the stirred suspension via a syringe. The reaction mixture was stirred overnight at r.t. and the suspension was filtered to remove salts over celite. After evaporation of the solvents under vacuum 1 was obtained pure as a white powder. Yield: $1.33 \mathrm{~g}(1.07 \mathrm{mmol}, 82 \%) .{ }^{1} \mathrm{H}$ NMR $\left(\mathrm{CDCl}_{3}\right):=\delta 7.54\left(\mathrm{dt}, 4 \mathrm{H},{ }^{1} J=7.6 \mathrm{~Hz},{ }^{2} J=1.6 \mathrm{~Hz}\right), 7.35(\mathrm{dq}$, $\left.6 \mathrm{H},{ }^{1} J=7.6 \mathrm{~Hz},{ }^{1} J=1.6 \mathrm{~Hz}\right), 1.77\left(\right.$ br s, $\left.c-\mathrm{C}_{5} \mathrm{H}_{9}\right), 1.61-1.49(\mathrm{br}$ $\left.\mathrm{m}, c-\mathrm{C}_{5} \mathrm{H}_{9}\right), 1.00\left(\mathrm{~m}, c-\mathrm{C}_{5} \mathrm{H}_{9}\right) \cdot{ }^{13} \mathrm{C}\{1 \mathrm{H}\} \mathrm{NMR}\left(\mathrm{CDCl}_{3}\right): \delta=132.6$ $\left(\mathrm{d}, J_{\mathrm{P}-\mathrm{C}}=2.4 \mathrm{~Hz}\right), 130.7\left(\mathrm{~d}, J_{\mathrm{P}-\mathrm{C}}=11.4 \mathrm{~Hz}\right), 129.5,129.3,129.0$, $128.8,128.1\left(\mathrm{~d}, J_{\mathrm{P}-\mathrm{C}}=7.6 \mathrm{~Hz}\right), 126.4,125.3,124.9,124.0,31.6$, 31.5, 31.3, 29.7, 27.3, 27.2, 27.1, 27.0, 26.9, 22.2, 22.1, 22.0 (1:3:3 ratio for $\left.\mathrm{C}_{\mathrm{ipso}} \mathrm{H}\right) .{ }^{31} \mathrm{P}\{1 \mathrm{H}\} \mathrm{NMR}\left(\mathrm{CDCl}_{3}\right)$ : $\delta=101.6$ (s). Anal. calcd. for $\mathrm{C}_{47} \mathrm{H}_{73} \mathrm{O}_{13} \mathrm{PSi}_{8}$ :C 51.24, H 6.68; found: C 51.35, H 6.78.

\section{$\left(c-\mathrm{C}_{5} \mathrm{H}_{9}\right)_{7} \mathrm{Si}_{8} \mathrm{O}_{12} \mathrm{O}$-dibenzo $[d, f]-2,2^{\prime}, 4,4^{\prime}$-tetra-tert- butyl-[1,3,2]dioxaphosphepin (2)}

A $(0.37 \mathrm{~g}, 0.39 \mathrm{mmol})$ was dissolved under moderate heating in $20 \mathrm{~mL}$ toluene giving a turbid white suspension. While stirring at r.t. a solution of dibenzo[ $d, f]-3,3^{\prime}, 5,5^{\prime}$-tetra-tert-butyl[1,3,2]dioxaphosphepin $P$-chloride $(0.16 \mathrm{~g}, 0.39 \mathrm{mmol})$ in $4 \mathrm{~mL}$ toluene was added dropwise via a syringe and the reaction mixture was stirred for 16 hours. Then salts were removed by filtration by cannula and the filtrate was concentrated by removal of the solvents under vacuum. The product was extracted by addition of $15 \mathrm{~mL}$ hexanes. Solvents were removed by evaporation, leaving $\mathbf{2}$ as a brown solid. Yield: $0.42 \mathrm{~g}(0.31 \mathrm{mmol}, 79 \%) .{ }^{1} \mathrm{H} \mathrm{NMR}\left(\mathrm{CDCl}_{3}\right): \delta=7.44(\mathrm{~d}, 4 \mathrm{H}$, $\left.{ }^{1} J=2.4 \mathrm{~Hz}\right), 7.18\left(\mathrm{~d}, 4 \mathrm{H},{ }^{1} \mathrm{~J}=2.4 \mathrm{~Hz}\right), 1.78-1.33$ (br m, $c$ $\left.\mathrm{C}_{5} \mathrm{H}_{9}\right), 1.00\left(\mathrm{~m}, c-\mathrm{C}_{5} \mathrm{H}_{9}\right) \cdot{ }^{13} \mathrm{C}\{1 \mathrm{H}\}$ NMR $\left(\mathrm{CDCl}_{3}\right): \delta=146.0$, $145.3\left(\mathrm{~d}, J_{\mathrm{P}-\mathrm{C}}=16.8 \mathrm{~Hz}\right), 126.4,125.3,124.9,124.0,31.6,31.5$, 31.3, 29.7, 27.3, 27.2, 27.0, 26.9, 22.2, 22.1, 22.0 (1:3:3 ratio for $\left.\mathrm{C}_{\mathrm{ipso}} \mathrm{H}\right) .{ }^{31} \mathrm{P}\{1 \mathrm{H}\}$ NMR $\left(\mathrm{CDCl}_{3}\right): \delta=132.6(\mathrm{~s})$.

\section{$\left(c-\mathrm{C}_{5} \mathrm{H}_{9}\right)_{7} \mathrm{Si}_{7} \mathrm{O}_{9}\left(\mathrm{OSiMePh}_{2}\right)$-bis-dibenzo $[d, f]-2,2^{\prime}, 4,4^{\prime}$ - tetra-tert-butyl-[1,3,2] dioxaphosphepin (3)}

B $(1.30 \mathrm{~g}, 1.21 \mathrm{mmol})$ was dissolved in $20 \mathrm{~mL}$ toluene and $\mathrm{NEt}_{3}$ $(0.36 \mathrm{~g}, 3.59 \mathrm{mmol})$ was added. While stirring at r.t. dibenzo[d, f]-3,3',5,5'-tetra-tert-butyl-[1,3,2]dioxaphosphepin $P$ chloride $(1.15 \mathrm{~g}, 2.42 \mathrm{mmol})$ in $5 \mathrm{~mL}$ toluene was added dropwise via a syringe and the reaction continued for 16 hours. The solution was concentrated to about $5 \mathrm{~mL}$ and then extracted by addition of $10 \mathrm{~mL}$ hexanes. After removal of solvents under vacuum $\mathbf{3}$ was obtained as a slightly brown solid. Yield: $2.12 \mathrm{~g}(90 \%)$. Recrystallization from a hot mixture of $\mathrm{CH}_{2} \mathrm{Cl}_{2} / \mathrm{CH}_{3} \mathrm{CN}(1: 2)$ afforded colourless rectangular single crystals, suitable for X-ray analysis. ${ }^{1} \mathrm{H}$ NMR $\left(\mathrm{CDCl}_{3}\right): \delta=7.64$ $\left(\mathrm{d}, 2 \mathrm{H},{ }^{1} \mathrm{~J}=2.4 \mathrm{~Hz}\right), 7.62\left(\mathrm{~d}, 2 \mathrm{H},{ }^{1} \mathrm{~J}=2.4 \mathrm{~Hz}\right), 7.45\left(\mathrm{~d}, 2 \mathrm{H},{ }^{1} J=\right.$ $2.4 \mathrm{~Hz}), 7.38\left(\mathrm{~d}, 2 \mathrm{H},{ }^{1} \mathrm{~J}=2.4 \mathrm{~Hz}\right), 7.32\left(\mathrm{dd}, 6 \mathrm{H},{ }^{1} \mathrm{~J}=5.6 \mathrm{~Hz},{ }^{2} J=\right.$ $2.4 \mathrm{~Hz}), 7.16\left(\mathrm{~d}, 2 \mathrm{H},{ }^{1} J=2.4 \mathrm{~Hz}\right), 7.14\left(\mathrm{~d}, 2 \mathrm{H},{ }^{1} J=2.4 \mathrm{~Hz}\right)$, $1.82-1.68\left(\right.$ br s, $\left.c-\mathrm{C}_{5} \mathrm{H}_{9}\right), 1.63-1.40\left(\right.$ br m, $\left.c-\mathrm{C}_{5} \mathrm{H}_{9}\right), 1.56(\mathrm{~s}), 1.38$ $(\mathrm{s}), 1.36(\mathrm{~s}), 1.28(\mathrm{~s}), 0.98-0.89\left(\mathrm{br} \mathrm{m}, c-\mathrm{C}_{5} \mathrm{H}_{9}\right), 0.15(\mathrm{~s}$, $\left.\mathrm{SiMePh}_{2}\right) \cdot{ }^{13} \mathrm{C}\{1 \mathrm{H}\} \mathrm{NMR}\left(\mathrm{CDCl}_{3}\right): \delta=152.8,146.0,145.6\left(\mathrm{~d}, J_{\mathrm{P}-}\right.$ $\left.\mathrm{C}_{\mathrm{C}}=16.8 \mathrm{~Hz}\right), 140.5\left(\mathrm{~d}, J_{\mathrm{P}-\mathrm{C}}=24.5 \mathrm{~Hz}\right), 137.8,134.1,133.5,129.2$, $127.7,126.1\left(\mathrm{~d}, J_{\mathrm{P}-\mathrm{C}}=13.7 \mathrm{~Hz}\right), 123.8,35.4,35.0,34.6(\mathrm{~d}), 31.6$ $(\mathrm{d}), 31.2(\mathrm{~d}), 27.8\left(\mathrm{~d}, J_{\mathrm{P}-\mathrm{C}}=3.0 \mathrm{~Hz}\right), 27.6\left(\mathrm{~d}, J_{\mathrm{P}-\mathrm{C}}=4.5 \mathrm{~Hz}\right), 27.3$, 27.0, 26.9, 26.8, 26.7, 24.8, 24.2, 24.1, 23.6, 22.4 (2:1:1:2:1 ratio for $\left.\mathrm{C}_{\mathrm{ipso}} \mathrm{H}\right),-0.4\left(\mathrm{Si} M e \mathrm{Ph}_{2}\right) \cdot{ }^{31} \mathrm{P}\{1 \mathrm{H}\} \mathrm{NMR}\left(\mathrm{CDCl}_{3}\right): \delta=131.3$ (s). Anal. calcd. for $\mathrm{C}_{104} \mathrm{H}_{156} \mathrm{O}_{16} \mathrm{P}_{2} \mathrm{Si}_{8}$ : C 64.09, $\mathrm{H}$ 8.07; found: $\mathrm{C}$ 63.85, H 7.95 .

\section{trans-[ $\left.\operatorname{PtCl}_{2}(2)_{2}\right]$ (complex 4)}

$\mathrm{PtCl}_{2}$ (cod) (22.4 mg, $\left.0.06 \mathrm{mmol}\right)$ and 2 (162.7 mg, $\left.0.12 \mathrm{mmol}\right)$ were dissolved in $5 \mathrm{~mL} \mathrm{CH} \mathrm{Cl}_{2}$ and stirred for 2 hours at r.t. 
After removal of the solvent, $\mathbf{4}$ was obtained as a yellow solid. By slow diffusion of $\mathrm{CH}_{3} \mathrm{CN}$ into a $\mathrm{CH}_{2} \mathrm{Cl}_{2}$ solution of this compound, colourless cubic single crystals could be grown, suitable for X-ray analysis. ${ }^{1} \mathrm{H}$ NMR $\left(\mathrm{CDCl}_{3}\right): \delta=7.43(\mathrm{~d}, 2 \mathrm{H}$, $\left.{ }^{1} J=2.4 \mathrm{~Hz}\right), 7.41\left(\mathrm{~d}, 2 \mathrm{H},{ }^{1} J=2.4 \mathrm{~Hz}\right), 7.15\left(\mathrm{~d}, 2 \mathrm{H},{ }^{1} J=2.4 \mathrm{~Hz}\right)$, $7.10\left(\mathrm{~d}, 2 \mathrm{H},{ }^{1} J=2.4 \mathrm{~Hz}\right), 1.83-1.26\left(\mathrm{br} \mathrm{m}, c-\mathrm{C}_{5} \mathrm{H}_{9}\right), 1.63(\mathrm{~s}, t-$ $\mathrm{Bu}), 1.60(\mathrm{~s}, t-\mathrm{Bu}), 1.47(\mathrm{~s}, t-\mathrm{Bu}), 1.36(\mathrm{~s}, t-\mathrm{Bu}), 1.34(\mathrm{~s}, t-\mathrm{Bu})$, $1.06-0.85$ (br m, $\left.c-\mathrm{C}_{5} \mathrm{H}_{9}\right) \cdot{ }^{31} \mathrm{P}\{1 \mathrm{H}\}$ NMR (toluene- $d_{8}$ ): $\delta=81.5$ $\left(\mathrm{s}, J_{\mathrm{Pt}-\mathrm{P}}=4680 \mathrm{~Hz}\right)$. Anal. calcd for $\mathrm{C}_{126} \mathrm{H}_{206} \mathrm{Cl}_{2} \mathrm{O}_{30} \mathrm{P}_{2} \mathrm{PtSi}_{16}: \mathrm{C}$ 50.81, H 6.97; found: C 50.68, H 7.10.

\section{trans-[PdCl $\mathbf{2}(3)]$ (complex 5)}

$\mathrm{PdCl}_{2}$ (cod) $(8.4 \mathrm{mg}, 29.4 \mu \mathrm{mol})$ and $\mathbf{3}(58.7 \mathrm{mg}, 30.1 \mu \mathrm{mol})$ were stirred in $5 \mathrm{~mL} \mathrm{CH}_{2} \mathrm{Cl}_{2}$ for $1.5 \mathrm{~h}$ to leave 5 as a yellow solid after removal of the solvent. Layering with $\mathrm{CH}_{2} \mathrm{Cl}_{2} / \mathrm{CH}_{3} \mathrm{CN}$ gave yellow rectangular single crystals, suitable for $\mathrm{X}$-ray analysis. ${ }^{1} \mathrm{H}$ NMR $\left(\mathrm{CDCl}_{3}\right): \delta=7.66\left(\mathrm{dd}, 4 \mathrm{H},{ }^{1} J=76 \mathrm{~Hz},{ }^{2} J=\right.$ $1.2 \mathrm{~Hz}), 7.43\left(\mathrm{~d}, 2 \mathrm{H},{ }^{1} \mathrm{~J}=2.4 \mathrm{~Hz}\right), 7.38\left(\mathrm{t}, 8 \mathrm{H},{ }^{1} \mathrm{~J}=7.2 \mathrm{~Hz}\right), 7.19$ $\left(\mathrm{d}, 2 \mathrm{H},{ }^{1} J=2.4 \mathrm{~Hz}\right), 7.04\left(\mathrm{~d}, 2 \mathrm{H},{ }^{1} \mathrm{~J}=2.4 \mathrm{~Hz}\right), 1.83-1.18(\mathrm{br} \mathrm{m}$, $\left.c-\mathrm{C}_{5} \mathrm{H}_{9}\right), 1.61(\mathrm{~s}, t-\mathrm{Bu}), 1.49(\mathrm{~s}, t-\mathrm{Bu}), 1.36(\mathrm{~s}, t-\mathrm{Bu}), 1.34(\mathrm{~s}, t-\mathrm{Bu})$, 1.31 (br s), $0.92\left(\mathrm{~s}, \mathrm{SiMePh}_{2}\right), 0.80\left(\mathrm{~m}, c-\mathrm{C}_{5} \mathrm{H}_{9}\right) .{ }^{13} \mathrm{C}\{1 \mathrm{H}\} \mathrm{NMR}$ $\left(\mathrm{CDCl}_{3}\right): \delta=146.7,141.3,139.7,137.7,134.4,134.1,132.5$, $130.9,129.3,128.8,127.5,126.3,124.9,124.1,36.1,35.3,34.6$, $32.4,31.5$ (d), 31.2, 30.4, 28.9, 27.9, 27.7, 27.6, 27.5, 27.3, 27.1, 27.0, 26.9, 26.4, 26.3, 24.4, 24.3, 23.8, 23.0, $22.5(1: 2: 2: 1: 1$ ratio for $\left.\mathrm{C}_{\mathrm{ipso}} \mathrm{H}\right) ; 1.1\left(\mathrm{SiMePh}_{2}\right) \cdot{ }^{31} \mathrm{P}\{1 \mathrm{H}\} \mathrm{NMR}\left(\mathrm{CDCl}_{3}\right): \delta=88.9(\mathrm{~s})$. Anal. calcd for $\mathrm{C}_{104} \mathrm{H}_{156} \mathrm{Cl}_{2} \mathrm{O}_{16} \mathrm{P}_{2} \mathrm{PdSi}_{8}$ : C 58.75, H 7.39; found: C 58.68, H 7.42.

\section{cis-[Mo(CO) $\left.{ }_{4}(3)\right]$ (complex 6$)$}

$\mathrm{Mo}(\mathrm{CO})_{4}(\text { pip })_{2} \quad(27.2 \mathrm{mg}, \quad 71.9 \mu \mathrm{mol})$ and 3 (154.6 mg, $79.0 \mu \mathrm{mol}$ ) were dissolved in $10 \mathrm{~mL} \mathrm{CH}_{2} \mathrm{Cl}_{2}$ and stirred for 2 hours at r.t. Then the solvent was concentrated to approx. $3 \mathrm{~mL}$ under vacuum, $5 \mathrm{~mL}$ of acetonitrile were added to precipitate the desired product as an off-white powder. After isolation of the powder, further washing with $4 \mathrm{~mL}$ of acetonitrile followed by drying under vacuum yielded $\mathbf{6}$ as a light-yellow solid. Upon slow diffusion of acetonitrile into a dichloromethane solution, yellow, parallelepiped single crystals were obtained, suitable for X-ray analysis. ${ }^{1} \mathrm{H} \mathrm{NMR}\left(\mathrm{CDCl}_{3}\right): \delta=7.68\left(\mathrm{dd}, 4 \mathrm{H},{ }^{1} J=7\right.$ $\left.6 \mathrm{~Hz},{ }^{2} J=1.2 \mathrm{~Hz}\right), 7.44\left(\mathrm{dd}, 6 \mathrm{H},{ }^{1} J=7.6 \mathrm{~Hz},{ }^{1} J=3.2 \mathrm{~Hz}\right), 7.41$ $\left(\mathrm{d}, 4 \mathrm{H},{ }^{1} \mathrm{~J}=7.2 \mathrm{~Hz}\right), 7.10\left(\mathrm{~d}, 2 \mathrm{H},{ }^{1} \mathrm{~J}=2.4 \mathrm{~Hz}\right), 7.01\left(\mathrm{~d}, 2 \mathrm{H},{ }^{1} \mathrm{~J}=\right.$ $2.4 \mathrm{~Hz}$ ), $1.84-1.68\left(\mathrm{br} \mathrm{m}, c-\mathrm{C}_{5} \mathrm{H}_{9}\right), 1.62(\mathrm{~s}, t-\mathrm{Bu}), 1.61-1.07$ (br $\left.\mathrm{m}, c-\mathrm{C}_{5} \mathrm{H}_{9}\right), 1.50(\mathrm{~s}, t-\mathrm{Bu}), 1.35(\mathrm{~s}, t-\mathrm{Bu}), 1.32(\mathrm{~s}, t-\mathrm{Bu}), 1.05-0.83$ (br m, $\left.c-\mathrm{C}_{5} \mathrm{H}_{9}\right), 0.80\left(\right.$ br m, $\left.c-\mathrm{C}_{5} \mathrm{H}_{9}\right), 0.75(\mathrm{~s}, t-\mathrm{Bu}), 0.11$ (s, $\left.\mathrm{SiCH} \mathrm{Ph}_{2}\right) \cdot{ }^{13} \mathrm{C}\{1 \mathrm{H}\}$ NMR $\left(\mathrm{CDCl}_{3}\right): \delta=146.7,146.3,140.0$, 139.4, 137.5, 134.3, 134.0, 133.0, 132.1, 129.5, 127.8, 127.6, 126.7, $126.0,123.8,36.2,35.7,34.5,34.4,33.0,32.3,31.5$ (d), 31.3, 31.2, 28.2, 28.1, 28.0, 27.7, 27.4, 27.2, 27.1, 27.0, 26.9, 26.8, 26.7, 26.6, 26.2 (d), 25.7, 24.9, 24.0, 22.6, $22.1\left(1: 2: 2: 1: 1\right.$ ratio for $\left.\mathrm{C}_{\mathrm{ipso}} \mathrm{H}\right)$; $1.1\left(\mathrm{SiMePh}_{2}\right) \cdot{ }^{31} \mathrm{P}\{1 \mathrm{H}\}$ NMR $\left(\mathrm{CDCl}_{3}\right): \delta=149.6(\mathrm{~s})$. FTIR (ATR mode, solid): $v=2041.3$ (st), 1947.9 (st), 1935.2 (st) and $1922.3 \mathrm{~cm}^{-1}$ (st). Anal. calcd. for $\mathrm{C}_{108} \mathrm{H}_{156} \mathrm{MoO}_{20} \mathrm{P}_{2} \mathrm{Si}_{8}: \mathrm{C} 60.14$, H 7.29; found: C 60.05, H 7.80.

\section{$\operatorname{Rh}(\mathrm{Cl})(\mathrm{CO})(3)]$ (complex 7):}

$\left[\mathrm{Rh}(\mu-\mathrm{Cl})(\mathrm{CO})_{2}\right]_{2} \quad(13.6 \mathrm{mg}, 34.9 \mu \mathrm{mol})$ and $\mathbf{3}$ (136.6 mg, $70.1 \mu \mathrm{mol})$ were stirred in $5 \mathrm{~mL}$ of refluxing toluene for 16 hours, giving a reddish brown solution. The ${ }^{31} \mathrm{P}\{1 \mathrm{H}\}$ NMR showed the existence of two species, both doublets. The major product A ( $\sim 90 \%$ based on NMR intensity) appeared at $111.9 \mathrm{ppm}$ with a coupling constant $J_{\mathrm{Rh}-\mathrm{P}}$ of $278 \mathrm{~Hz}$, while the minor product $\mathbf{B}$ appeared at $120.7 \mathrm{ppm}$ with a coupling constant $J_{\mathrm{Rh}-\mathrm{P}}$ of $217 \mathrm{~Hz}$. Layering a dichloromethane solution of the yellow-brown solid with acetonitrile yielded yellow cubic single crystals. From the X-ray crystallographic analysis these were shown to be the minor product $\mathbf{B}$ (complex 7). ${ }^{1} \mathrm{H} \mathrm{NMR}\left(\mathrm{CDCl}_{3}\right): \delta=7.78($ br s, $2 \mathrm{H}), 7.66\left(\mathrm{dd}, 2 \mathrm{H},{ }^{1} J=7.6 \mathrm{~Hz}\right.$, $\left.{ }^{2} J=2.4 \mathrm{~Hz}\right), 7.55$ (br d, $\left.2 \mathrm{H}\right), 7.49($ br s, $2 \mathrm{H}), 7.42$ (br d, $4 \mathrm{H},{ }^{1} J=$ $7.2 \mathrm{~Hz}$ ), 7.37 (br d, 2H), 7.15 (br s, 2H), 7.12 (br s, 2H), $1.83-$ $1.18\left(\right.$ br m, $\left.c-\mathrm{C}_{5} \mathrm{H}_{9}\right), 1.61(\mathrm{~s}, t-\mathrm{Bu}), 1.49(\mathrm{~s}, t-\mathrm{Bu}), 1.36(\mathrm{~s}, t-\mathrm{Bu})$, $1.34(\mathrm{~s}, t-\mathrm{Bu}), 1.31$ (br s), $0.92\left(\mathrm{~s}, \mathrm{SiMePh}_{2}\right), 0.80\left(\mathrm{~m}, c-\mathrm{C}_{5} \mathrm{H}_{9}\right)$. ${ }^{31} \mathrm{P}\{1 \mathrm{H}\} \mathrm{NMR}\left(\mathrm{CDCl}_{3}\right): \delta=120.7\left(\mathrm{~d}, J_{\mathrm{Rh}-\mathrm{P}}=217 \mathrm{~Hz}\right), 111.9(\mathrm{~d}$, $J_{\text {Rh-P }}=278 \mathrm{~Hz}$ ). FTIR (ATR mode, solid): $v=2019,2009 \mathrm{~cm}^{-1}$ [st, $\mathrm{Rh}(C O)$ ]. Anal. calcd. for $\mathrm{C}_{105} \mathrm{H}_{156} \mathrm{ClO}_{17} \mathrm{P}_{2} \mathrm{RhSi}_{8}$ : C 59.62, $\mathrm{H}$ 7.43; found: C 58.86, H 7.45.

\section{Hydroformylation of 1-Octene}

The 1-octene was dried by flushing over neutral activated alumina to remove peroxide impurities. A 75-mL stainless steel autoclave with inner glass beaker and magnetic stirrer inside was used. $\mathrm{Rh}(\mathrm{acac})(\mathrm{CO})_{2}(2.00 \mathrm{mg}, 7.75 \mu \mathrm{mol})$ and the ligand (10 equivs.) were dissolved separately in $5 \mathrm{~mL}$ toluene, then combined and transferred to the autoclave under argon. The autoclave was purged three times with syngas and then pressurized to 20 bar. After $1 \mathrm{~h}$ of preformation the substrate solution, containing 1-octene $(31.0 \mathrm{mmol}), n$-decane (12.5 mmol) and toluene $(2.7 \mathrm{~mL})$ was added, 20 bar of syngas was applied at $80^{\circ} \mathrm{C}$ and the reaction was run for the appropriate time. The reaction was stopped immediately by cooling down the autoclave in an ice bath to r.t. and then slowly depressurizing it. A sample was withdrawn for GC analysis.

\section{Crystal Structure Determination of 4}

Intensity data were collected on a Nonius Kappa CCD diffractometer with rotating anode. The structure was solved by direct methods using SHELXS86, ${ }^{[47 a]}$ and refined on $F^{2}$ by least-squares procedures using SHELXL97. ${ }^{[48]}$ All non-hydrogen atoms were refined with anisotropic displacement parameters. Hydrogen atoms were constrained to idealized geometries and allowed to ride on their carrier atoms with an isotropic displacement parameter related to the equivalent displacement parameter of their carrier atoms. Most cyclopentyl and tert-butyl groups were disordered and restraints were necessary to obtain reasonable geometries. The unit cells also contained voids filled with disordered solvent $\left(\mathrm{CH}_{2} \mathrm{Cl}_{2} /\right.$ $\mathrm{CH}_{3} \mathrm{CN}$ ). The solvent contribution was taken into account using PLATON/SQUEEZE (1920 ^³/unit cell and 629 electrons). Structure validation and molecular graphics preparation were performed with the PLATON package. ${ }^{[49]}$ Crystal data are given in Table 2. 
Table 2. Selected crystallographic data for complex 4.

\begin{tabular}{lc}
\hline & $\mathbf{4}$ \\
\hline Formula & $\mathrm{C}_{126} \mathrm{H}_{206} \mathrm{Cl}_{2} \mathrm{O}_{30} \mathrm{P}_{2} \mathrm{PtSi}_{16}$ \\
$\mathrm{FW}\left(\mathrm{g} \cdot \mathrm{mol}^{-1}\right)$ & 2978.31 \\
Crystal system & Monoclinic \\
Space group & $P 2_{1} / c($ no. 14$)$ \\
$a(\AA)$ & $13.486(2)$ \\
$b(\AA)$ & $27.985(4)$ \\
$c(\AA)$ & $42.300(7)$ \\
$\beta\left({ }^{\circ}\right)$ & $90.730(10)$ \\
$V\left(\AA^{3}\right)$ & $15963(4)$ \\
$Z$ & 4 \\
$d_{\text {calc }}\left(\mathrm{g} \mathrm{cm}^{-3}\right)$ & $1.2393(3)$ \\
$\left.\mu(\mathrm{Mo}-\mathrm{K} \alpha)(\mathrm{mm})^{-1}\right)$ & 1.115 \\
$\mathrm{~T}(\mathrm{~K})$ & 150 \\
Total reflections & 164471 \\
$\mathrm{Unique} \mathrm{reflections}^{-}\left(R_{\text {int }}\right)$ & $25029(0.143)$ \\
$w R_{2}\left(\mathrm{~F}^{2}\right)($ all data $)$ & 0.299 \\
$\lambda(\AA)$ & 0.71073 \\
$R_{1}(\mathrm{~F})$ & 0.098 \\
$F(000)$ & 6272 \\
\hline
\end{tabular}

$R_{\text {int }}=\Sigma\left[\mid F_{o}^{2}-F_{o}^{2}(\right.$ mean $\left.) \mid\right] \Sigma\left[F_{o}^{2}\right]$

$w R\left(F^{2}\right)=\left[\Sigma\left[\mathrm{w}\left(F_{o}^{2}-F_{c}^{2}\right)^{2}\right] / \Sigma\left[w\left(\mathrm{~F}_{\mathrm{o}}^{2}\right)^{2}\right]\right]^{1 / 2}$;

$R(F)=\Sigma\left(|| F_{o}|-| F_{c}||\right) / \Sigma\left|F_{o}\right|$.

\section{Crystal Structure Determinations of 3, 5 and 7}

Diffraction data were collected on a Nonius Kappa CCD diffractometer with rotating anode at $150 \mathrm{~K}$. PLATON/ DELABS was used to correct the data of complex 3 for absorption. The structures were solved by direct methods (SHELXS97 ${ }^{[47 b]}$ for 3 and SIR97 ${ }^{[47 c]}$ for 5) and Patterson methods (DIRDIF99 ${ }^{[47 \mathrm{~d}]}$ for 7). Least-squares refinement of $F^{2}$ was done with SHELXL97. ${ }^{[48]}$ Hydrogen atoms were introduced at calculated positions and refined riding on their carrier atom. Several of the tert-butyl and cyclopentyl moieties were refined with a disorder model in all three structures. Structures 3 and 7 contain voids ( $393 \AA^{3} /$ unit cell for 3 and $2460 \AA^{3}$ for $\mathbf{7}$, with 83 and 418 recovered electrons, respectively) filled with severely disordered solvents $\left(\mathrm{CH}_{2} \mathrm{Cl}_{2} / \mathrm{CH}_{3} \mathrm{CN}\right)$. Their contribution to the structure factors was taken into account in the least-squares refinement using the PLATON/SQUEEZE ${ }^{[49]}$ procedure. Structure validation and molecular graphics were performed with the PLATON package. ${ }^{[49]}$ Crystal data are given in Table 3 .

\section{Crystal Structure Determination of 6}

The data were collected on a Bruker SMART APEX CCD. Data integration and global cell refinement was performed with the program $S A I N T$. Intensity data were corrected for Lorentz and polarization effects. The structure was solved by Patterson methods and extension of the model was accom-

Table 3. Selected crystallographic data for ligand 3 and the complexes 5-7.

\begin{tabular}{|c|c|c|c|c|}
\hline & 3 & 5 & 6 & 7 \\
\hline Formula & $\begin{array}{l}\mathrm{C}_{104} \mathrm{H}_{156} \mathrm{O}_{16} \mathrm{P}_{2} \mathrm{Si}_{8} \\
\text { + solvent }\end{array}$ & $\begin{array}{l}\mathrm{C}_{104} \mathrm{H}_{156} \mathrm{Cl}_{2} \mathrm{O}_{16} \mathrm{P}_{2} \mathrm{Si}_{8} \mathrm{Pd} \\
\cdot 2.52\left(\mathrm{CH}_{2} \mathrm{Cl}_{2}\right) \cdot 1.96\left(\mathrm{CH}_{3} \mathrm{CN}\right)\end{array}$ & $\begin{array}{l}\mathrm{C}_{108} \mathrm{H}_{156} \mathrm{MoO}_{20} \mathrm{P}_{2} \mathrm{Si}_{8} \cdot 2 \\
\cdot\left(\mathrm{CH}_{2} \mathrm{Cl}_{2}\right)\end{array}$ & $\begin{array}{l}\mathrm{C}_{106} \mathrm{H}_{156} \mathrm{Cl}_{2} \mathrm{O}_{18} \mathrm{P}_{2} \mathrm{Rh}_{2} \mathrm{Si}_{8} \\
+ \text { solvent }\end{array}$ \\
\hline $\mathrm{FW}\left(\mathrm{g} \cdot \mathrm{mol}^{-1}\right)$ & $1948.95^{\mathrm{a}}$ & 2420.86 & 2326.86 & $2281.70^{\mathrm{a}}$ \\
\hline Crystal size (mm) & $0.24 \times 0.36 \times 0.66$ & $0.09 \times 0.27 \times 0.52$ & $0.52 \times 0.44 \times 0.27$ & $0.05 \times 0.10 \times 0.30$ \\
\hline Crystal system & Triclinic & Monoclinic & Monoclinic & Orthorhombic \\
\hline Space group & $P \Sigma($ no. 2$)$ & $P 2_{1} / c($ no. 14$)$ & $P 2_{1} / a($ no. 14$)$ & $P 2_{1} 2_{1} 2_{1}($ no. 19$)$ \\
\hline$a(\AA)$ & $13.5395(1)$ & $13.7930(1)$ & $24.605(1)$ & $14.2366(10)$ \\
\hline$b(\AA)$ & $14.2578(1)$ & $32.0407(3)$ & $18.882(1)$ & $27.516(3)$ \\
\hline$c(\AA)$ & $29.4554(2)$ & $31.6221(3)$ & $25.723(1)$ & $33.591(3)$ \\
\hline$\alpha\left(^{\circ}\right)$ & $85.7071(3)$ & & & \\
\hline$\beta\left(^{\circ}\right)$ & $88.9721(3)$ & $114.492(10)$ & $90.162(5)$ & \\
\hline$\gamma\left({ }^{\circ}\right)$ & $87.7415(3)$ & & & \\
\hline$V\left(\AA^{3}\right)$ & $5665.17(7)$ & $12717.5(2)$ & $11950.6(9)$ & $13159(2)$ \\
\hline$Z$ & 2 & 4 & 4 & 4 \\
\hline$d_{\text {calc }}\left(\mathrm{g} \mathrm{cm}^{-3}\right)$ & $1.143^{\mathrm{a}}$ & 1.265 & 1.279 & $1.1517^{[\mathrm{a}]}$ \\
\hline$\mu(\mathrm{Mo}-\mathrm{K} \alpha)\left(\mathrm{mm}^{-1}\right)$ & $0.181^{\mathrm{a}}$ & 0.452 & 0.326 & $0.442^{\mathrm{a}}$ \\
\hline $\mathrm{T}(\mathrm{K})$ & 150 & 150 & 100 & 150 \\
\hline Total reflections & 93379 & 75341 & $108533^{\mathrm{a}}$ & 331952 \\
\hline Unique reflections $\left(R_{\text {int }}\right)$ & $22295(0.061)$ & $22387(0.054)$ & $29433(0.057)$ & $30194(0.062)$ \\
\hline$w R_{2}\left(\mathrm{~F}^{2}\right)($ all data $)$ & 0.1471 & 0.1441 & 0.2312 & 0.110 \\
\hline$\lambda(\AA)$ & 0.71073 & 0.71073 & 0.71073 & 0.71073 \\
\hline$R_{1}(\mathrm{~F})$ & 0.0533 & 0.0564 & 0.0808 & 0.041 \\
\hline$F(000)$ & $2100^{\mathrm{a}}$ & 5116 & 4916 & $4808^{\mathrm{a}}$ \\
\hline
\end{tabular}

$R_{\text {int }}=\Sigma\left[\mid F_{o}^{2}-F_{o}^{2}(\right.$ mean $\left.) \mid\right] / \Sigma\left[F_{o}^{2}\right]$;

$w R\left(F^{2}\right)=\left[\Sigma\left[\mathrm{w}\left(F_{o}^{2}-F_{c}^{2}\right)^{2}\right] / \Sigma\left[w\left(\mathrm{~F}_{\mathrm{o}}^{2}\right)^{2}\right]\right]^{1 / 2}$;

$R(F)=\Sigma\left(|| F_{o}|-| F_{c}||\right) / \Sigma\left|F_{o}\right|$.

[a] Without disordered solvent contribution. 
plished by direct methods applied to difference structure factors using the program DIRDIF ${ }^{[47 \mathrm{~d}]}$ The positional and anisotropic displacement parameters for the non-hydrogen atoms were refined. Refinement was frustrated by a disorder problem: from the solution, it was clear that one of the dichloromethane solvent molecules was highly disordered and probably partly occupied. The $B Y P A S S$ procedure ${ }^{[50]}$ was used to take into account the electron density in the potential solvent area, which resulted in an electron count of 31 , within a volume of $269 \AA^{3}$ in the unit cell. The hydrogen atoms were included in the final refinement riding on the $\mathrm{C}$-atom as appropriate with $U_{i s o}=c \times U_{\text {equiv }}$. Final refinement on $F^{2}$ carried out by full-matrix least-squares techniques converged at $w R\left(F^{2}\right)=0.1057$ for 21387 reflections and $R(F)=0.0375$ for 18554 reflections with $F_{\mathrm{o}} \geq$ in $4.0 \sigma \% \mathrm{~s}\left(F_{o}\right)$ and 975 parameters. Crystal data are given in Table 3.

Crystallographic data (excluding structure factors) for the structure(s) reported in this paper have been deposited with the Cambridge Crystallographic Data Centre as supplementary publication no. CCDC-220025 (3), 222225 (4), $220026-$ $220028(5-7)$. Copies of the data can be obtained free of charge on application to CCDC, 12 Union Road, Cambridge CB2 1EZ, UK [fax.: (internat.) (+44)-1223/336-033; e-mail: deposit@ccdc.cam.ac.uk.

\section{Acknowledgements}

This research was financially supported by the National Research School Combination for Catalysis (NRSCC) and in part (A. M. M. and A. L. S.) by the Netherlands Foundation of Chemical Research (SON) with financial aid from the Netherlands Organisation for Scientific Research (CW-NWO). OMG is acknowledged for a generous gift of various transition metal precursors. The Erasmus Program of the European Union is thanked for a travel grant (J. A.). Drs. Michiel Grutters is thanked for scientific discussions.

\section{References and Notes}

[1] J. F. Brown, L. H. Vogt, J. Am. Chem. Soc. 1965, 87, 4313.

[2] a) F. J. Feher, R. Terroba, J. W. Ziller, Chem. Commun. 1999, 2309; b) F. J. Feher, R. Terroba, J. W. Ziller, Chem. Commun., 1999, 2153.

[3] a) M. G. Voronkov, V. L. Lavrent'yev, Top. Curr. Chem. 1982, 102, 199; b) F. J. Feher, K. D. Wyndham, Chem. Commun. 1998, 323; c) F. J. Feher, K. D. Wyndham, M. A. Scialdone, Y. Hamuro, Chem. Commun. 1998, 1469; d) F. J. Feher, K. D. Wyndham, D. J. Knauer, Chem. Commun. 1998, 2393; e) P. P. Pescarmona, T. Maschmeyer, Austr. J. Chem. 2001, 54, 583.

[4] a) F. J. Feher, D. A. Newman, J. F. Walzer, J. Am. Chem. Soc. 1989, 111, 1741; b) F. T. Edelmann, Angew. Chem. Int. Ed., 1992, 31, 586; c) R. Duchateau, R. J. Harmsen, H. C. L. Abbenhuis, R. A. van Santen, A. Meetsma, S. K.-H. Thiele, M. Kranenburg, Chem. Eur. J. 1999, 5, 3130; d) F. T. Edelmann, Y. K. Gun'ko, S. Giessman, F. Olbrich, Inorg. Chem. 1999, 38, 210; e) T. W. Dijkstra, R. Duchateau, R. A. van Santen, A. Meetsma, G. P. A. Yap, J. Am. Chem. Soc. 2002, 124, 9856.
[5] a) F. J. Feher, R. Terroba, R. Z. Jin, K. D. Wyndham, S. Lucke, R. Brutchey, F. Nguyen, Polym. Mater. Sci. Eng. 2000, 82, 301; b) J. Choi, J. Harcup, A. F. Yee, Q. Zhu, R. M. Laine, J. Am. Chem. Soc. 2001, 123, 11420; c) N. Maxim, P. C. M. M. Magusin, P. J. Kooyman, J. H. M. C. van Wolput, R. A. van Santen, H. C. L. Abbenhuis, Chem. Mater. 2001, 13, 2958.

[6] a) F. J. Feher, T. A. Budzichowski, Polyhedron 1995, 14, 3239; b) V. Lorenz, A. Fischer, S. Giesmann, J. W. Gilje, Y. K. Gun'ko, K. Jacob, F. T. Edelmann, Coord. Chem. Rev. 2000, 206-207, 321; c) R. Duchateau, Chem. Rev. 2002, 102, 3525; d) R. W. J. M. Hanssen, R. A. van Santen, H. C. L. Abbenhuis, Eur. J. Inorg.Chem. 2004, 675.

[7] H. C. L. Abbenhuis, Chem. Eur. J. 2000, 6, 25.

[8] a) H. C. L. Abbenhuis, S. Krijnen, R. A. van Santen, Chem. Commun. 1997, 331; b) M. Crocker, R. H. Herold, A. G. Orpen, M .Overgaag, J. Chem. Soc. Dalton Trans. 1999, 3791; c) S. Krijnen, B. L. Mojet, H. C. L. Abbenhuis, J. H. C. van Hooff, R. A. van Santen, Phys. Chem. Chem. Phys. 1999, 1, 361; d) P. P. Pescarmona, J. C. van der Waal, I. E. Maxwell, T. Maschmeyer, Angew. Chem. Int. Ed. 2001, 40, 740; e) M. D. SworonskaPtasinska, M. L. W. Vorstenbosch, R. A. van Santen, H. C. L. Abbenhuis, Angew. Chem. Int. Ed. 2002, 41, 637; P. P. Pescarmona, T. Maschmeyer, J. C. van der Waal, Chem. Eng. Commun. 2004, 191, 68.

[9] For silsesquioxanes with only one phosphorus functionality see: a) F. J. Feher, T. A. Budzichowski, Organometallics 1991, 10, 812; b) B. J. Hendan, H. C. Marsmann, Appl. Organomet. Chem. 1999, 13, 287; c) Z. Fei, R. Schmutzler, F. T. Edelmann, Z. Anorg. Allg. Chem. 2003, 629, 353.

[10] a) F. J. Feher, J. J. Schwab, S. H. Philips, A. Eklund, E. Martinez, Organometallics 1995, 14, 4452; b) B. Hong, P. S. Toms, H. J. Murfee, M. J. Lebrun, Inorg. Chem. 1997, 36, 6146; c) S. Lücke, K. Stoppek-Langner, J. Kuchinke, B. Krebs, J. Organomet. Chem. 1999, 584, 11; d) F. J. Feher, K. D. Wyndham, D. Soulivong, F. Nguyen, J. Chem. Soc. Dalton Trans. 1999, 1491; e) K. Wada, D. Izuhara, M. Shiotsuki, T. Kondo, T. Mitsudo, Chem. Lett. 2001, 31, 734.

[11] L. Ropartz, D. F. Foster, R. E. Morris, A. M. Z. Slawin, D. J. Cole-Hamilton, Chem. Commun. 2001, 361; b) L. Ropartz, R. E. Morris, D. F. Foster, D. J. Cole-Hamilton, J. Mol. Cat. A.: Chem. 2002, 182-183, 99; c) L. Ropartz, D. F. Foster, R. E. Morris, A. M. Z. Slawin, D. J. ColeHamilton, J. Chem. Soc. Dalton Trans. 2002, 1997; d) L. Ropartz, K. J. Haxton, D. F. Foster, R. E. Morris, A. M. Z. Slawin, D. J. Cole-Hamilton, J. Chem. Soc. Dalton Trans. 2002, 4323.

[12] a) F. J. Feher, T.A . Budzichowski, J. Organomet. Chem. 1989, 379, 33; b) F. J. Feher, J. F. Walzer, R. L. Blanski, J. Am. Chem. Soc. 1991, 113, 3618; c) F. J. Feher, T. L. Tajima, J. Am. Chem. Soc. 1994, 116, 2145.

[13] a) P. W. N. M. van Leeuwen, C. F. Roobeek, (to Shell), British Patent 2068377, 1980; Chem. Abstr. 1984, 101, 191142; b) P. W. N. M. van Leeuwen, C. F. Roobeek, J. Organomet. Chem. 1983, 258, 343. 
[14] a) R. Sablong, U. Schlotterbeck, D. Vogt, S. Mecking, Adv. Synth. Catal. 2003, 345, 333; b) H. P. Dijkstra, N. Ronde, G. P. M. van Klink, D. Vogt, G. van Koten, $A d v$. Synth. Catal. 2003, 345, 364; c) H. P. Dijkstra, C. A. Kruithof, N, Ronde, R. van de Coevering, D. J. Ramon, D. Vogt, G. P. M. van Klink, G. van Koten, J. Org. Chem. 2003, 68, 675; d) M. D. Meijer, N. Ronde, D. Vogt, G. P. M. van Klink, G. van Koten, Organometallics 2001, 20, 3993; e) D. de Groot, J. C. de Wilde, R. J. van Haaren, J. N. H. Reek, P. C. J. Kamer, P. W. N. M. van Leeuwen, E. B. Eggeling, D. Vogt, H. Kooijman, A. L. Spek, A. W. van der Made, Chem. Commun. 1999, 1623; f) N. J. Hovestad, E. B. Eggeling, H. J. Heidbuchel, J. T. B. H. Jastrzebski, U. Kragl, W. Keim, D. Vogt, G. van Koten, Angew. Chem. Int. Ed. 1999, 38, 1655.

[15] J. I. van der Vlugt, M. M. P. Grutters, J. Ackerstaff, R. W. J. M. Hanssen, H. C. L. Abbenhuis, D. Vogt, Tetrahedron Lett. 2003, 44, 8301.

[16] a) J. I. van der Vlugt, M. Fioroni, J. Ackerstaff, R. W. J. M. Hanssen, A. M. Mills, A. L. Spek, A. Meetsma, H. C. L Abbenhuis, D. Vogt, Organometallics 2003, 22, 5297; b) M. Fioroni, J. I. van der Vlugt, D. Vogt, unpublished work.

[17] R. L. Pruett, J. A. Smith, J. Org. Chem., 1969, 34, 327. b) R. L. Pruett, J. A. Smith, (to Union Carbide), South African Patent 6,804,937, 1968; Chem. Abstr. 1969, 71, 90819.

[18] a) E. Billig, A. G. Abatjoglou, D. R. Bryant, (to Union Carbide), U. S. Patent 4,769,498, 1987; Chem. Abstr. 1987, 14, 3081; b) T. Omatsu, (to Kururay), European Patent 303,060, 1989; Chem. Abstr. 1989, 111, 38870; c) T. Jongsma, G. Challa, P. W. N. M. van Leeuwen, J. Organomet. Chem. 1991, 421, 121; d) A. van Rooy, E. N. Orij, P. C. J. Kamer, P. W. N. M. van Leeuwen, Organometallics 1995, 14, 34 .

[19] a) E. Billig, A. G. Abatjoglou, D. R. Bryant, (to Union Carbide), U. S. Patent 4,668,651, 1987; Chem. Abstr. 1987, 107, 7392; b) K. Sato, Y. Karawagi, M. Takai, T. Ookoshi, (to Mitsubishi), U. S. Patent 5,235,113, 1993; Chem. Abstr. 1993, 118, 191183; c) P. M. Burke, J. M. Garner, W. Tam, K. A. Kreutzer, A. J. J. M. Teunissen, (to DSM/Du Pont), WO 97 33854, 1997; Chem. Abstr. 1997, 127, 294939.

[20] R. Duchateau, H. C. L. Abbenhuis, R. A. van Santen, S. K.-H. Thiele, M. F. H. van Tol, Organometallics, 1998, 17, 5222.

[21] Modified procedure, see: F. J. Feher, K. Rahimian, T. A. Budzichowski, J. W. Ziller, Organometallics 1995, 14, 3920; R. Duchateau, U. Cremer, R. J. Harmsen, S. I. Mohamud, H. C. L. Abbenhuis, R. A. van Santen, A. Meetsma, S. K. -H. Thiele, M. F. H. van Tol, M. Kranenburg, Organometallics 1999, $18,5447$.

[22] F. J. Feher, T. A. Budzichowski, R. L. Blanski, K. J. Weller, J. W. Ziller, Organometallics 1991, 10, 2526.

[23] a) M. D. Sworonska-Ptasinska, R. Duchateau, R. A. van Santen, G. P. A. Yap, Eur. J. Inorg. Chem. 2001, 133; b) M. D. Sworonska-Ptasinska, R. Duchateau, R. A. van Santen, G. P. A. Yap, Organometallics 2001, 20, 3519.

[24] C. J. Cobley, P. G. Pringle, Inorg. Chim. Acta 1997, 265, 107.
[25] J. R. Severn, R. Duchateau , R. A. van Santen, D. D. Ellis, A. L. Spek, G. P. A. Yap, J. Chem. Soc. Dalton Trans. 2003, 2294.

[26] a) E. E. Nifantyev, E. N. Rasadkina, L. K. Vasyanina, V. K. Belsky, A. I. Stash, J. Organomet. Chem. 1997, 529, 171; b) S. Cserépi-Szücs, G. Huttner, L. Zsolnai, J. Bakos, J. Organomet. Chem. 1999, 586, 70; c) S. Steyer, C. Jeunesse, D. Matt, R. Welter, M. Wesolek, J. Chem. Soc. Dalton Trans. 2002, 4264.

[27] F. J. Parlevliet, M. A. Zuideveld, C. Kiener, H. Kooijman, A. L. Spek, P. C. J. Kamer, P. W. N. M. van Leeuwen, Organometallics 1999, 18, 3394; S. J. Sabounchei, A. Nagipour, J. F. Bickley, Acta Cryst. C 2000, 56, 280.

[28] T. Gebauer, G. Frenzen, K. Dehnicke, Z. Naturforsch. B 1993, $48,1661$.

[29] a) M. Hariharasarma, C. H. Lake, C. L. Watkins, G. M. Gray, Organometallics 1999, 18, 2593; b) M. Hariharasarma, C. H. Lake, C. L. Watkins, G. M. Gray, J. Organomet. Chem. 1999, 580, 328; c) G. M. Gray, K. A. Redmill, J. Organomet. Chem. 1985, 280, 105.

[30] a) V. Sum, M. T. Patel, T. P. Kee, M. Thornton-Pett, Polyhedron 1992, 11, 1743; b) V. Sum, T. P. Kee, M. Thornton-Pett, J. Organomet. Chem. 1992, 438, 89; c) N. Greene, H. Taylor, T. P. Kee, M. Thornton-Pett, J. Chem. Soc. Dalton Trans. 1993, 821.

[31] E. C. Alyea, G. Ferguson, M. Zwikker, Acta Cryst. C 1994, 50, 676.

[32] G. M. Gray, F. P. Fish, D. K. Srivastava, A. Varshney, M. J. van der Woerd, S. E. Ealick, J. Organomet. Chem. 1990, 385, 49.

[33] J. K. Hogg, S. L. James, A. G. Orpen, P. G. Pringle, J. Organomet. Chem. 1994, 480, 1.

[34] J. I. van der Vlugt, M. M. P. Grutters, A. M. Mills, H. Kooijman, A. L. Spek, D. Vogt, Eur. J. Inorg. Chem. 2003, 4361.

[35] J. I. van der Vlugt, R. Sablong, A. M. Mills, H. Kooijman, A. L. Spek, A. Meetsma, D. Vogt, Dalton Trans. 2003, 4690.

[36] a) F. Bachechi, L. Zambonelli, L. M. Venanzi, Helv. Chim. Acta 1977, 60, 2815; b) A. Ceriotti, G. Ciani, A. Sironi, J. Organomet. Chem. 1983, 247, 345; c) M. Sawamura, H. Hamashima, M. Sugawara, R. Kuwano, Y. Ito, Organometallics 1995, 14, 4549; d) A. Marinetti, V. Kruger, C. Le Menn, L. Ricard, J. Organomet. Chem. 1996, 522, 223; e) A. M. Trzeciak, T. Głowiak, R. Grzybek, J. J. Ziółkowski, J. Chem. Soc. Dalton Trans. 1997, 1831; f) D. C. Smith Jr., E. D. Stevens, S. P. Nolan, Inorg. Chem. 1999, 38, 5277; g) D. Armspach, D. Matt, Chem. Commun. 1999, 1073; h) S. C. van der Slot, P. C. J. Kamer, P. W. N. M. van Leeuwen, J. Fraanje, K. Goubitz, M. Lutz, A. L. Spek, Organometallics 2000, 19, 2504; i) E. B. Bauer, J. Ruwwe, J. M. Martín-Alvarez, T. B. Peters, J. C. Bohling, F. A. Hampel, S. Szafert, T. Lis, J. A. Gladysz, Chem. Commun. 2001, 2261; j) C. M. Thomas, R. Mafua, B. Therrien, E. Rusanov, H. Stœckli-Evans, G. Süss-Fink, Chem. Eur. J. 2002, 8, 3343.

[37] a) E. K. van der Beuken, W. G. J. de Lange, P. W. N. M. van Leeuwen, N. Veldman, A. L. Spek, B. L. Feringa, J. Chem. Soc. Dalton Trans. 1996, 3561; b) R. Paciello, L 
Siggel, H. J. Kneuper, N. Walker, M. Röper, J. Mol. Cat. A: Chem. 1999, 143, 85; c) P. Le Gendre, E. Maubrou, O. Blacque, G. Boni, C. Moïse, Eur. J. Inorg. Chem. 2001, 1437; d) K. A. Bunten, D. H. Farrar, A. J. Poë, A. Lough, Organometallics 2002, 21, 3344.

[38] a) N. Sakai, K. Nozaki, K. Mashima, H. Takaya, Tetrahedron: Asymmetry 1992, 3, 583; b) G. H. J. Buisman, E. J. Vos, P. C. J. J. Kamer, P. W. N. M. van Leeuwen, J. Chem. Soc. Dalton Trans. 1995, 409.

[39] a) A. Maisonnat, P. Kalck, R. Poilblanc, Inorg. Chem. 1974, 13, 661; b) J. J. Bonnet, Y. Jeannin, P. Kalck, A. Maisonnat, R. Poilblanc, Inorg. Chem. 1975, 14, 743.

[40] E. Fernández, A. Ruiz, C. Claver, S. Castillón, A. Polo, J. F. Piniella, A. Alvarez-Larena, Organometallics 1998, 17, 2857.

[41] a) C. J. Cobley, D. D. Ellis, A. G. Orpen, P. G. Pringle, J. Chem. Soc. Dalton Trans. 2000, 1109; b) C. J. Cobley, D. D. Ellis, A. G. Orpen, P. G. Pringle, J. Chem. Soc. Dalton Trans. 2000, 1101.

[42] K. N. Gavrilov, A. T. Teleshev, A. R. Bekker, N. N. Nevskii, E. E. Nifant'ev, Zh. Obsch. Khim. 1993, 63, 2791.
[43] S. Ini, A. G. Oliver, T. D. Tilley, R. G. Bergman, Organometallics 2001, 20, 3839.

[44] S. D. Pastor, S. P. Shum, R. K. Rodebaugh, A. D. Debellis, F. H. Clarke, Helv. Chim. Acta 1993, 76, 900.

[45] D. R. Drew, J. R. Doyle, Inorg. Synth. 1990, 28, 346.

[46] D. J. Darensbourg, R. L. Kump, Inorg. Chem. 1978, 17, 2680.

[47] a) G. M. Sheldrick, SHELXS86, University of Göttingen, Germany, 1986; b) G. M. Sheldrick, SHELXS97, University of Göttingen, Germany, 1997; c) A. Altomare, M. C. Burla, M. Camalli, G. L. Cascarano, C. Giacovazzo, A. Guagliardi, A. G. G. Moliterni, G. Polidori, R. Spagna, J. Appl. Cryst. 1999, 32, 115; d) P. T. Beurskens, G. Beurskens, R. de Gelder, S. GarcíaGranda, R. O. Gould, R. Israël, J. M. M. Smits, The DIRDIF-99 program system, University of Nijmegen, The Netherlands, 1999.

[48] G. M. Sheldrick, SHELXL97, University of Göttingen, Germany, 1997.

[49] A. L. Spek, PLATON, A Multipurpose Crystallographic Tool, Utrecht University, The Netherlands, 2002.

[50] P. van der Sluis, A. L. Spek, Acta Cryst. A 1990, 46, 194. 